\title{
UM ESTUDO FENOMENOLÓGICO SOBRE O FILME “A PELE QUE
}

HABITO"

\section{A PHENOMENOLOGICAL STUDY ON THE MOVIE “THE SKIN I LIVE IN"}

\author{
Maria Aparecida Viggiani Bicudo ${ }^{1}$ \\ Débora Candido de Azevedo ${ }^{2}$
}

\begin{abstract}
Resumo: Este estudo da película A Pele que Habito foi realizado da perspectiva fenomenológica e traz uma descrição do filme tomado como a coisa, ela mesma, mote da fenomenologia, lançando luz sobre o que ele nos traz, como a pele que eu habito. Buscamos compreender do que se trata essa pele, olhada na totalidade do corpo-vivente entendido como unidade física-psíquica-espiritual ${ }^{3}$ que, na temporalidade e espacialidade do mundo-vida que habita junto aos outros, vivencia experiências e se dá conta de si, vivenciando-as. Nosso estudo aponta para a compreensão de que a pele que eu habito diz do corpo-vivente que sou no fluxo contínuo das vivências que vão se entrelaçando e constituindo, pelos atos da consciência, pelas retenções e protensões do vivenciado, estilos de modos de ser da pessoa olhada em todos seus aspectos, destacando-se as diferenças e nuanças do modo de ser pessoa do sexo masculino e do sexo feminino.
\end{abstract}

Palavras Chave: Fenomenologia; Corpo-vivente; Antropologia dual; A Pele que Habito.

Abstract: This study on the film The Skin I Live In was carried out from the phenomenological perspective, describing it as the thing itself, theme of phenomenology, shedding light on what it brings to us, as the skin I live in. We attempted to understand what this skin is about, seen from the wholeness of the lived body understood as physical-psychical-spiritual ${ }^{3}$ unit that, in the temporality and spatiality of the lifeworld that live next to others, senses experiences, and realizes itself, experiencing them. Our study points to the comprehension that the skin I live in represents the lived body that I am in the continuous flow of experiences that intertwine and become, through acts of conscience, retentions and protensions of the experienced, styles of being of the person, seen considering all aspects, highlighting differences and shades of the mode of being of the male and female genders.

Keywords: Phenomenology; Lived body; Dual anthropology, The Skin I Live In.

\section{Introdução}

Dado o tema impactante que aborda, o filme dirigido por Pedro Almodóvar

\footnotetext{
${ }^{1}$ Doutora em Ciências pela Faculdade de Filosofia Ciências e Letras de Rio Claro (FFCLRC). Professora Titular de Filosofia da Educação, aposentada na Univesidade Estadual Paulista "Júlio de Mesquita Filho" (UNESP). Professora do Programa de Pós-Graduação em Educação Matemática na na Univesidade Estadual Paulista "Júlio de Mesquita Filho" (UNESP) Rio Claro, São Paulo, Brasil. E-mail: mariabicudo@gmail.com

${ }^{2}$ Mestre em Educação pela Universidade Paulista (UNIP). Psicóloga clínica e docente da Universidade Paulista (UNIP), São Paulo, São Paulo, Brasil. E-mail: debora@fluirpsicologia.com.br

${ }^{3}$ Espiritual, no âmbito da fenomenologia diz dos atos de ajuizamento e de valoração que dão sustentação às escolhas com base nesses ajuizamentos.
} 
intitulado A Pele que Habito (2011) tem sido objeto de muitos estudos e debates. O núcleo do tema é a mudança do gênero masculino para o gênero feminino de um jovem rapaz. A trama traz outros assuntos importantes e comuns na atualidade do mundo-vida em que estamos: diferença, violência, estupro, virgindade. Do ponto de vista da Filosofia e da Psicologia, põe em foco a pessoa, o Eu, o corpo vivente, os modos de ser-com. Da perspectiva cinematográfica, solicita análises sobre imagens, sons, cores, movimento e cenas superpostas que dão vida à trama, colocando em jogo o visível e o invisível do intencionado pelo diretor. Enfim, sem pretender abranger todos os temas significativos e importantes do filme, queremos dizer da genialidade do diretor, do impacto que nos causa o que é abordado no filme, e de sua beleza. Damo-nos conta de que são muitas as perspectivas das quais pode ser olhado, pois a película desvela significados compreendidos e interpretados por alguns que, contudo, não foram vistos ou destacados por outros.

Nossa proposta é apresentar um estudo fenomenológico entendido como um modo de olhar, analisar e interpretar o longa-metragem.

O desenvolvimento deste texto traz (i) uma descrição sucinta do filme e, sendo descrição (BICUDO, 2011), não é entrelaçada com interpretações; (ii) alguns estudos que consideramos significativos para evidenciar diferentes olhares sobre o filme; (iii) a pergunta que dirigimos a ele, a qual orienta nossa análise e interpretação; (iv) a perspectiva da qual o olhamos; (v) o modo pelo qual procedemos visando perseguir a pergunta formulada e (vi) o estudo realizado.

\section{Descrição do filme A Pele que Habito}

Abordando temas polêmicos e atuais, A Pele que Habito (2011) é um filme que tem a complexidade do existir do ser humano como pano de fundo. Traz ao debate temas significativos e presentes no mundo-vida em que vivemos, como a violência, a não observação de questões éticas ao se querer um resultado a qualquer custo, a sexualidade, a ciência e a tecnologia, o estupro, a subjugação. O filme é de uma beleza e uma plasticidade que prende o expectador, convidando-o a vivenciar, junto aos personagens, as emoções destes.

A trama se desenrola em torno do protagonista Robert Ledgard, cirurgião plástico que também se dedica a estudos experimentais científicos. Rico, Robert reside em uma mansão arquitetonicamente imponente e artisticamente decorada com objetos de arte 
variados, como tapetes, quadros de pintores famosos, esculturas e livros. Sua história de vida carrega paixões, perdas, lutos e traições, embora seja bem-sucedido profissional e economicamente. O enredo entrelaça os fantasmas que habitam em Robert, a dor da traição de sua esposa Gal quando esta foge com Zeca, a perda da filha Norma pelo suicídio, e sua impotência em salvá-la e dela aproximar-se como pai. Robert se nutre do sentimento de vingança canalizado para o jovem Vicente, suposto estuprador de Norma, psiquicamente perturbada desde o trágico suicídio de sua mãe, por ela presenciado.

A situação de estupro de Norma é ambígua, dado o desencontro de mundos expressos no diálogo estabelecido entre ela e seu jovem parceiro, Vicente. Incapaz de se situar socialmente na festa em que se encontra, Norma não entende os sinais de aproximação amorosa do jovem, com quem conversa. Este a convida a sair para o jardim, onde Norma se refere a drogas como os remédios psiquiátricos que toma; por sua vez, Vicente vivencia uma aproximação amorosa, busca uma relação sexual, como fazem os demais jovens casais convidados, e fala sobre drogas como entorpecentes, dos quais é usuário, como revela-se comum naquele ambiente.

Vicente passa, então, a coprotagonizar o filme junto a Robert. A vingança deste incide sobre aquele, agora visto como o estuprador de Norma. Vicente é raptado e mantido prisioneiro na mansão de Robert. Este o toma como matéria de suas experiências científicas, ao mudar o sexo de Vicente de masculino para feminino por meio da primeira de uma série de cirurgias, uma vaginoplastia. Ao final do processo Vicente encontra-se transformado em Vera, nome com o qual Robert batiza sua criação quando esta atinge o grau de perfeição pretendido: corpo de mulher, pele perfeita criada artificialmente em experimentos e voz feminina em consequência da administração de hormônios. Em seu novo rosto Vera traz a fisionomia de Gal, que havia traído Robert com Zeca e se suicidado durante um tratamento para queimaduras graves administrado pelo marido.

Na mansão se encontram Vicente/Vera, Robert, a governanta Marilia, que, no desenrolar do filme, revela-se mãe biológica e afetiva de Robert e de Zeca. Marilia era empregada na casa do Sr. Ledgard, pai de Robert, de quem engravidou e cuja esposa era estéril. O casal Ledgard adota Robert, e Marilia permanece na casa, cuidando de todos. Zeca é filho dela com outro homem, mas esta criança não viveu sempre a seu lado. Foi criada sobretudo na rua e apresenta modos de se comportar que indicam transtornos. Por ter fugido com Gal e causado o acidente que a queimou, ele é proibido de voltar àquela casa.

Cientista bem-sucedido, Robert se apresenta à comunidade científica, expondo 
seu experimento que visa criar pele artificial, semelhante à humana, capaz de substituir esta quando necessário, como em casos de queimaduras. Questionados por seus pares, diz que denominou essa pele "Gal”, em homenagem a sua esposa. Porém, é questionado sobre os aspectos éticos de suas experiências transgênicas, já que havia sido proibido de realizálas com humanos. A despeito desta proibição, Robert continua com estas no corpo de Vicente, revelando-se cientista frio conduzido por um projeto próprio de criar corpos perfeitos, dominado por sentimentos de ódio e vingança. À medida que Vicente se transfigura em Vera, esta passa a ser um risco iminente para Robert, que pode ter seus experimentos descobertos.

Vicente trabalhava com sua mãe, proprietária de um atelier, e com Cristina, funcionária do estabelecimento. Ele vestia manequins femininos com cuidado e se mostrava apreciador das roupas que sua mãe costurava. Certa vez Vicente declara que acha um vestido bonito e o oferece de presente a Cristina, convidando-a a vesti-lo naquela noite para sair com ele. Ela diz que tem namorada, revelando assim sua orientação sexual. Diz ainda a Vicente que, se gosta tanto do vestido, por que não o veste?

A relação de Robert com Vicente é caracterizada pelo assujeitamento deste à medida que aquele o transforma, sem seu consentimento, e usa seu corpo como matéria corpórea não humana. Mas, à proporção que Vera surge por completo, sendo-lhe retirada a máscara cirúrgica e tendo seu rosto desvelado, Robert volta-se mais para ela, afastandose aos poucos do ódio que sentia. Vera percebe o interesse crescente de Robert por ela e busca corresponder a suas expectativas, com a meta de ganhar sua confiança. Vicente, embora transformado em Vera, tem o plano de fugir, libertando-se. São várias as tentativas realizadas com esse intuito, desde a busca de rotas de fuga da mansão até o suicídio.

Vera se percebe como mulher bonita, olhada com desejo por Robert. Há cenas em que paira certa ambiguidade sobre os sentimentos e desejos de Vera por Robert, sobre a manipulação do desejo que ele sente por ela; Vera, todavia, não abandona o objetivo de se libertar.

Mas a chegada inesperada e inoportuna de Zeca altera o rumo do projeto de Robert com Vicente/Vera. Contundo, o cientista mantém-se controlador da situação. Zeca descobre a existência de Vera, confundindo-o com Gal. Ao procurá-la, Zeca abre a porta do quarto e Vicente/Vera vê a oportunidade de realizar seu objetivo: fugir. Vera entra em um jogo com Zeca; mas, sem controle sobre sua volúpia, este a estupra. No ato, Zeca a machuca, pois é virgem; em sua forma feminina, Vicente/Vera nunca havia mantido 
relações sexuais. Robert presencia o estupro, pega uma arma, adentra o quarto e atira em Zeca, matando-o. Neste momento modificam-se as relações estabelecidas: Vera sai do quarto pela primeira vez, para fora das paredes da mansão, permanecendo aconchegada junto a Marilia no calor de uma fogueira em que queimam os lençóis ensanguentados retirados da cama em que fora estuprada. Marilia relata uma vida cheia de traições, perdas e sofrimentos de Robert. Este retorna, pois fora enterrar Zeca, e acrescenta mais tecidos à fogueira. Em clima de ternura, Robert convida-as a entrar, coloca os braços nos ombros de Vera, que nele se aconchega em postura que traduz sentimento de proteção.

Marilia não confia em Vera e sempre enfatiza sua previsão de que, ou Vera mata Robert, ou Robert mata Vera, já que, conhecendo toda a história pregressa deste, não antevê outro desfecho. Vera e Robert vivem momentos que indicam levarem uma vida de casal; ela, assumindo-se mulher e ganhando a confiança dele, saindo à rua com Marilia para fazer compras. Em determinado momento do filme, Vera vai ao atelier de sua mãe e compra o vestido de que havia gostado, seis anos antes. Entretanto, a harmonia no cotidiano, que satisfaz Robert, apaixonado por Vera, ou melhor, pelo corpo que criou, rompe-se com a chegada de Fulgencio, cirurgião colega de Robert que participou da vaginoplastia de Vicente. O visitante questiona as experiências de Robert, notando que, na época em que a cirurgia foi realizada, observou tratar-se de um paciente muito jovem, deixando escapar suspeitas sobre o processo cirúrgico. $\mathrm{O}$ visitante traz consigo a edição recente de um jornal contendo uma reportagem sobre pessoas desaparecidas. Esta mostra a foto de Vicente e relata que a mãe deste continua procurando-o, mesmo depois de seis anos. Robert ameaça seu colega, com um revólver. Suas dúvidas são atenuadas ou banidas com a chegada de Vera que, ao ouvir as últimas falas de Fulgencio, apresenta-se, sentase no colo de Robert, beija-o apaixonadamente e afirma ter sido uma escolha sua. Fulgencio se retira.

A confiança de Robert em Vera aumenta. Durante uma relação sexual consensual entre o casal, Vera diz que a penetração ainda dói e vai em busca de um lubrificante, que havia comprado de antemão. Procura-o em sua bolsa. Diz não o encontrar; desce as escadas e vai até ao escritório, onde vê o jornal e as fotos de Vicente e o depoimento de sua mãe. Vera pega o revólver, sobe e se dirige a Robert, que espera por ela com ansiedade. Porém, Vicente/Vera atira nele, matando-o. Marilia, ora inquieta, sobe as escadas e entra no quarto, também armada. Ao ver Robert morto e ensanguentado, sai atrás de Vera para matá-la. Mas esta a mata antes. Em seguida Vera se veste com o vestido que havia querido dar a Cristina, agasalha-se com um casaco de couro vermelho, pega 
dinheiro de Robert e sai. Abre as portas da casa, caminha e toma um táxi para sua antiga casa. Vera se faz reconhecer por Cristina. Em seguida, entra em cena sua mãe, que se depara com uma atmosfera de forte emoção e pergunta quem é essa mulher, referindo-se à Vera. Vicente/Vera diz: sou eu, Vicente.

\section{Estudos que evidenciam as diferentes perspectivas a partir das quais o filme é olhado}

Trazemos citações de alguns textos que apresentam discussões do filme sob diferentes perspectivas para evidenciar os modos possíveis de compreendê-lo e, então, dizermos daquela da qual o olharemos. Para fins de ilustração destas diferentes perspectivas citamos os autores e seus trabalhos, sem, contudo, enveredar por um estudo bibliográfico extenso dos artigos relevantes escritos sobre o filme ou avaliar cada trabalho sobre o filme e o tema de sua trama.

Breder e Coelho (2017) publicaram um excelente estudo intitulado Desvelando Imagens: o Visível e o Indizível na Pele que Habitamos, realizado da perspectiva da plasticidade do corpo e da fluidez do gênero tal como entendido por Judith Butler. Neste ponto queremos pontuar que entendemos, como Ales Bello (2017), que a pessoa é uma totalidade entendida de acordo com a Antropologia Dual, que traz consigo a igualdade primeira e se diferencia em gêneros masculino e feminino, os quais dizem dos sexos biológicos que também se diferenciam em particulares e nuanças de acordo com as individualidades que apresentam. Concordamos com Breder e Coelho (2017) sobre a inexistência de uma categoria fixa, imposta biologicamente com rigidez, segundo a qual, nas palavras das autoras, o corpo é maleável e sua conformação é contínua, sendo o gênero redefinido mediante práticas discursivas contínuas. As autoras analisam o discurso explícito do filme, o qual versa sobre a plasticidade do corpo e a fluidez do gênero, enfatizando aspectos positivos quando se desvinculam categorizações fixas no modo de compreender estes aspectos. Analisam, também, o seu discurso implícito, considerando que todo o filme, por ser um produto de práticas sociais, carrega consigo um conjunto de ideias que escapam às próprias intenções do autor. Este modo de ver o dito no filme revela a polissemia da linguagem, possibilitando diferentes interpretações oriundas de perspectivas distintas a partir das quais se olha o filme, reveladoras das concepções assumidas por quem o olha e o interpreta. Evidencia também a impossibilidade de se chegar ou de se obter uma verdade, a qual o autor queira expor ou intérpretes e críticos 
pretendam impor.

Em O que Faz um Corpo? Comentário em Torno de “A Pele que Habito”, Freire (2011) pensa o lugar do corpo na constituição do sujeito para a psicanálise. Desta perspectiva, analisa os comportamentos de Robert, cientista que, por conta de suas fantasias, mágoas, desejo de vingança por perdas dramáticas experienciadas quer, valendo-se de seu conhecimento e domínio de técnicas cirúrgicas, criar um outro, nas vezes de objeto de seu gozo. Analisa, então, o outro criado por Robert, que sobrevive às experiências sucessivas para que seja transformado de homem em mulher. Este outro explora tentativas para sair desta situação, incialmente buscando fugir do local em que se encontra; fugir de si e de sua vida, suicidando-se, ou matando o Outro (Robert) que vê. Ainda outra tentativa de sobrevivência é explorada pela autora, quando discute o corpo em uma ascese, encontrada como que por acaso em um programa didático na TV, na ioga, em exercícios de postura, elasticidade e alongamento. Por meio dessa disciplina corporal à qual, enclausurado, dedica-se com afinco, “[...] o sujeito consegue construir um vazio idealizado pela busca de si, o que lhe propicia produzir avulsas uma nova amarração, costura de um novo corpo com peças forjadas pelo Outro” (FREIRE, 2011, p. 2).

Freire (2011) trabalha o assujeitamento da criatura que se oferece ao Outro, que a ele se oferece, pois é a única coisa que me resta, e aponta o modo como o desejo refaz o circuito pulsional, ecoando no novo corpo um novo dizer.

Em A Pele que Habito e a Dupla Subversão de Gênero, Vianna (2013) apresenta um ensaio sobre cinema na seção Ensaios sobre Cinema. O autor nos chama a atenção para o processo da formação do elenco e todo o cuidado com que Pedro Almodóvar cerca a composição dos cenários, trazendo a presença de livros, de quadros de arte, de citação de autores. A materialidade plástica recorre a luzes, movimento, sequências e sobreposições fotogramáticas, sons apropriados, escolha de figurino e caracterização dos personagens para nos fazer adentrar a realidade vivenciada por estes, enredando-nos na trama. Chama-nos a, com ele, olhar a recorrente presença da liminaridade nos detalhes cênicos, os quais mantêm vínculo orgânico com a trama principal. Para Viana, tudo no filme foi estruturado para romper com algumas expectativas de gênero literáriocinematográfico e sexual, no combate a simplificações. Por meio de uma situação-limite (a transexualidade forçada, como forma de vingança) evidenciam-se as convenções que fundam a potencial violência simbólica e física dos preconceitos e fronteiras socioculturais que configuram expectativas sobre papéis sexuais e afetivos.

Maria Poesia (2012) escreve uma resenha do filme A Pele que Habito, na qual 
afirma que, entre as muitas direções que uma análise do filme pode tomar, a autora optou por concentrar-se no personagem Vicente. Para ela, o filme aborda o tema da identidade com sabedoria, expondo a concepção de que, longe de sermos seres cristalizados no tempo, somos gradativamente moldados por nossas experiências. O que somos é uma soma do aparato biológico e das várias experiências que se colocam em nossa personalidade. A autora declara que "somos atravessados por linhas invisíveis que se misturam no tempo e em nossa identidade substanciando, se presentificando e corporificando como atributos do eu, mas que pode ser alterado até o último dia de nossas vidas" (POESIA, 2012, p. 2).

Logo, somos capazes de nos reinventar, de reescrever nossa biografia, uma vez que podemos revisitá-la e reinterpretá-la. Para Maria Poesia, A Pele que (eu) Habito dizia de Vicente, o eu, a imagem corporal que o habitava. O cirurgião Robert emoldura em Vicente a estrutura corporal, não o que este era por dentro. Vicente é emoldurado com um invólucro, como uma máscara, e sobrevive aos horrores a que fora submetido; porém, ele volta para "casa", para o lugar em que habita, buscando pelas constantes presentes entre tantas variáveis mundanas. Dito de outro modo, busca encontrar os vínculos que permaneceram e deixaram rastros em sua vida.

Nós nos propomos a olhar o corpo-vivente da pessoa que, sem traçar e assumir um projeto de vida, é lançada ao mundo-vida ${ }^{4}$ em que se encontra em movimento de mudança do sexo masculino para o feminino. Nossa pergunta é, “Como o corpo-vivente vivencia experiências que vão constituindo as modificações no modo de ser/aparecer de uma pessoa do sexo masculino como uma pessoa do sexo feminino?"

\section{A pergunta por nós endereçada e o solo em que seu sentido se evidencia}

Na pergunta, “Como o corpo-vivente 5 vivencia experiências que vão constituindo modos de ser/aparecer de uma pessoa do sexo masculino como uma pessoa do sexo

\footnotetext{
${ }^{4}$ Mundo-vida; aqui estou me valendo de Husserl (1970); diz do mundo, tomado como uma totalidade em que realizamos nossas vivências situados na espacialidade e na temporalidade. Não é um recipiente em que somos colocados ou em que colocamos conhecimentos, teorias, etc. como se fossem objetos dados em sua empiricidade. É espacialidade e temporalidade em cujas dimensões vivemos com os outros, humanos ou não, cuja realidade vamos tecendo mediante compreensões expressas subjetiva e intersubjetivamente, materializadas por formas e conteúdos disponíveis. O intersubjetivamente compreendido que se mantém em repetições de ações bem-sucedidas constitui-se, paulatinamente, mediante entrelaçamentos de sentidos e de significados em objetualidades. É com estas que lidamos. Este, como entendo, é o próprio movimento de constituição do solo em rede no qual nos encontramos.

5 Também denominado corpo-encarnado, por Hursserl (2002), e corpo-próprio, por Merleau-Ponty (1994).
} 
feminino?" destacamos corpo-vivente, vivencia e constituindo.

O título do filme, A Pele que Habito, traz a imagem da pele como um invólucro do $e u$, que aqui poderia ser entendido como substância que mora neste invólucro. Fenomenologicamente, o corpo-vivente nos faz aparecer e tocar o mundo, ao mesmo tempo em que nos faz perceber estamos tocando o que está a nossa frente, sendo tocados pelo que ali está. É uma totalidade constituída de carne e osso, ou seja, de aspectos físicospsíquicos e espirituais. Portanto, o corpo humano não se reduz a uma estrutura composta pelo par psique e corpo, olhado em sua materialidade que, nas obras de Husserl (2002) e Merleau-Ponty (1994), é explicitado pela palavra Körper. Husserl expõe sua compreensão de corpo-vivente como entrelaçamento dos aspectos físicos, psíquicos e espirituais. Logo, evidencia ações nutridas pela intenção e a vontade de fazer algo em uma situação, ou seja, sempre se movendo em direção a algo a fazer. A concepção de corpo-vivente - corpo que vive e que se sente vivendo - é expressa pela palavra Leib. Leib traz a organização da alma entelequial que "[...] revela-se como um núcleo organizador das dimensões corpórea - do Körper - psíquicas, afetivas e espirituais" (SILVA, 2017, p. 27). A compreensão do entrelaçamento organizado do biológico/físico, psíquico $^{6}$ e espiritual encarnados nos aponta para a complexidade da pessoa. De acordo com Husserl, tal complexidade é passível de ser conhecida pelo estudo das vivências. Estas são específicas dos seres que apresentam capacidade experiencial, isto é, de realizar atos e de se darem conta dos atos que realizam.

De acordo com Ales Bello, “[...] essa é a novidade da análise do fenômeno do ser humano e pode-se acrescentar que o faz mediante a análise da experiência vivenciada pelo próprio ser humano, disso que ele vivencia [...] traduzida da palavra alemã de que se vale Husserl, Erlebnis" (ALES BELLO, 2017, p. 48).

As vivências ${ }^{7}$ se dão de modo qualitativamente diferenciado: as que são próprias

\footnotetext{
${ }^{6}$ A palavra psique, como exposto por Ales Bello (2015), é originária da língua grega e indica uma parte divina e imaterial do ser humano, também complexa, a qual diz do aspecto espiritual por excelência; além disso, é uma palavra epistemologicamente derivada dos atos divinos; ou seja, a psique é compreendida, tradicionalmente, como pertencente a um território que não faz parte do corpo, pois é imaterial: não podemos tocá-la. A psique é também o território dos atos de reação e de impulso; estes atos não apenas não são controlados por nós, como também vêm de forma espontânea. Por exemplo, quando dizemos a outra pessoa: neste momento tenho sede, esta pessoa que está conosco pode, no mesmo momento, não ter sede; mas isto não impede que ela entenda o que estou sentindo, pois sentir a necessidade de beber água é um sentimento comum entre as pessoas. Ela não consegue mensurar a sede que estou sentindo, mas tem a compreensão do que significa sentir sede.

${ }^{7}$ Do italiano vissuti, do inglês lived, do francês vècu; todas são traduções que buscam trazer o dito pela palavra alemã Erlebiniss. Em português existe a palavra vivência, que expressa o movimento do ato de vivenciar e, assim, diz mais da ideia que se busca expressar.
} 
à fisicalidade do corpo diferem daquelas próprias ao psíquico que, por sua vez, diferem daquelas do espírito. Enquanto os aspectos corpóreos e psíquicos estão mais presentes na literatura científica, na qual podem ser expostos de maneira objetiva, os espirituais estão envoltos em uma névoa de explicações que abarcam questões teológicas e filosóficas passíveis de serem expostas em tendências diversas. No âmbito da fenomenologia, espírito diz dos aspectos de julgamento e da tomada de decisão, evidenciando possibilidades do querer fazer tal coisa de tal modo com tal fim. Isto é, diz da possibilidade de liberdade. As vivências dizem do substrato decorrente da experiência vivenciada, a qual permanece no fluxo da lembrança e, longe de ser tomada como permanência estática, é vista como uma complexidade de estratos de sentidos que, no movimento de entrelaçamento, delineiam os indícios do sentido, evidenciando percepções que revelam um salto em direção à totalidade do percebido.

Vejamos como esta ideia é trabalhada em Husserl, especificamente no segundo volume de Ideias (2002), em que, de modo detalhado, descreve seu entendimento da constituição do corpo-vivo. Como dito acima, esse corpo é também biológico/físico, e, como tal, porta sensações localizadas. Ao olharmos para um corpo-vivente, "O que nos chega de imediato (sobre ou do corpo-vivente) é seu aspecto somático" (BICUDO, 2012, p. 91). Os assim denominados "órgãos do sentido", como o tato, a visão, a audição, por exemplo, e outras sensações mais elaboradas, como as cinestésicas, revelam-nos aspectos específicos da coisa percebida e, mais do que isso, a complexidade do sentido no e pelo corpo-vivo. Todas as sensações são localizadas, distinguindo-se em virtude dos pontos somáticos que afetam.

Mas o corpo-vivo passa a impor o seu modo de ser à medida que se mostra como coisa física, matéria, hylé que permite que se o olhe de modo objetivo, que também se mostra como um órgão que sensorialmente sente sensações que emanam de seus órgãos sensoriais como o tato, a audição, a visão, o paladar, o olfato, além de um sexto, mais complexo: a cinestesia. Entre os órgãos do sentido, Husserl concebe o tato com primazia. Explicita que é pelo tato que se dá, simultaneamente, a sensação de um objetual tocado, da parte localizada do corpo que o toca, e a sensação de sentir o que ocorre no corpovivo, entendido como um sistema. Dito de outro modo, os efeitos dos estímulos materiais externos não são sentidos como algo estranho, pontual, mas como inerentes à somaticidade, como um quê ordenado em termos de correspondência entre objetual e corpo-vivo. Ele é uma unidade peculiar de apreensão de doações das coisas da natureza ou do mundo externo. Husserl traz o seguinte exemplo esclarecedor: 
[...] para perceber esta coisa tátil que é este peso de papel que está sobre a mesa, eu o palpo com o dedo. Experimento, de modo tátil, a superfície lisa do vidro e suas saliências nítidas. Mas se considero a mão e o dedo dou-me conta que eles têm sensações de contato que continuam ainda quando a mão se recolhe; assim, o dedo e a mão têm sensações cinestésicas: aquelas mesmas sensações que agem indicando ou apresentando a coisa "peso" que funcionam como efeitos de contato do peso com a mão, como sensações localizadas produzidas nela. A mesma sensação da mão pousada na mesa é percebida ora como percepção da superfície da mesa (de uma pequena parte) e ora, sobre a base de uma outra "direção de atenção", de atualização de outro estrato da apreensão, conduz uma sensação de pressão sobre o dedo (HUSSERL, 2002, p. 149).

$\mathrm{Na}$ obra citada, Husserl descreve as especificidades dos modos pelos quais os órgãos dos sentidos nos trazem sensações. Sobre o órgão da visão, por exemplo, afirma que não encontramos o modo de sentir possibilitado pelo tato.

\begin{abstract}
Neles não se dá o fenômeno de dupla sensação. A coisa vista não está em contato direto com o olho, entendido como órgão, tocando-o. Vejo-me e vejo meu corpo. O corpo visto não é ao mesmo tempo algo que é visto e que vê. Quando me vejo ao espelho é como se estivesse vendo outro e não vendo meu próprio olho no ato de ver. Não é possível confrontar a relação entre a cor da coisa vista e o olho que vê a cor. O sentido da visão não é localizado. Tudo o que vemos permanece em nível de relações imediatas com o corpo vivo, não em decorrência de sua visibilidade, mas de sensações táteis conectadas às visíveis (BICUDO,2012, p.93).
\end{abstract}

Olhada à luz das ideias fenomenológicas sobre o corpo-vivente acima expostas, a pergunta por nós posta, "Como o corpo-vivente ${ }^{8}$ vivencia experiências que vão constituindo modos de ser/aparecer de uma pessoa do sexo masculino como uma pessoa do sexo feminino?", permite-nos dizer que não há um eu isolado que habita uma pele, mas há uma pessoa em constituição pelas vivências de ações realizadas e percebidas. É um corpo-próprio que se faz na temporalidade e espacialidade em que suas experiências se dão e são vivenciadas no movimento da vida que vive no mundo-vida com os outros.

Nesse caminho de compreensões compreendemos também a sexualidade do ser humano. O que caracteriza o ser humano não é seu aspecto psicofísico apenas, mas, sobretudo, seu modo de ser espiritual. Esse modo se expressa no que as Ciências Humanas estudam. Homem e mulher têm, em sua essência ${ }^{9}$, os mesmos traços humanos fundamentais, ao mesmo tempo iguais e diferentes. Iguais, no que diz respeito à espécie humana; diferentes, nos sexos feminino e masculino que, biologicamente, cada indivíduo traz em sua estrutura biológica. Entretanto, as diferenças sexuais que apresentam não são dois polos que os definem; ao contrário: trata-se de uma diferença dual, uma vez que todo ser humano traz em si aspectos da sexualidade feminina e da masculina. Essa visão está

\footnotetext{
${ }^{8}$ Também denominado corpo-encarnado, por Husserl (2002), e corpo-próprio, por Merleau-Ponty (1994).

${ }^{9}$ Entendida como sua característica nuclear.
} 
presente na Antropologia Dual de Edith Stein, conforme exposta por Ales Bello em Tutta Colpa di Eva (2017). Essa Antropologia Dual defende a ideia de que a diferença entre o masculino e o feminino é sustentada ao lado da unidade específica do ser humano. Ambos, homem e mulher, são seres humanos, e é nisto que consiste sua igualdade. Porém, são diferentes à proporção que não apenas o Körper é estruturado de modo diverso, como também o são algumas funções fisiológicas particulares, além das distinções na dinâmica de toda a vida do Leib. A interpretação fenomenológica da complexidade do ser humano, constituído pelo entrelaçamento funcional e dinâmico entre corpo físico, psíquico e espírito traz consigo modalidades diferenciadas de articulações do corpo-vivente cujo sexo é masculino ou feminino. Em linguagem cartesiana, são modos diferenciados de relações que se revelam entre alma e corpo, ou espírito e matéria; no próprio âmbito do psíquico, apresentam diferentes aspectos de expressões de sensibilidade, ao mesmo tempo que apresentam forças diferentes no âmbito do espírito. Em linguagem teórica, entretanto, a diferença pode ser vista de dois modos: diferente, portanto inferior; diferente, mas com uma especificidade própria que não elimina a igualdade entre ambos, homem e mulher, olhados como humanos. Esta teoria pode conduzir a duas saídas opostas: aceitar a submissão da mulher, isto é, a absolutização de um gênero contrapondo-o a outro, ou idealizar-se uma nova humanidade que considere a diferença na igualdade - igualdade esta que exige que toda pessoa, em suas diferenças, seja respeitada em sua dignidade. As autoras deste artigo assumem a validade do segundo cenário.

Portanto, neste estudo, o fazemos diferentemente da filosofia feminista dos anos 70 e 80 do século XX, que buscava a igualdade da mulher em relação ao masculino; diferentemente, também, da Gender Theory, que atribui a diferença entre os sexos à cultura e aos usos e costumes sociais. Ales Bello (2017) não afirma essa supremacia do cultural que propõe a desnaturalização da sexualidade, porém assume a Antropologia Dual, entendendo que o masculino e o feminino se exprimem de modo diverso e que, apesar disso, têm em comum a constituição da pessoa entendida como uma complexidade física (bio)-psíquica-espiritual.

Concordamos com Stein e Ales Bello e assumimos a igualdade de ambos os sexos, masculino e feminino, enquanto seres humanos sempre dignos de respeito e de acolhimento em suas diferenças. Reconhecer as diferenças em um pano de fundo em que esteja, a priori, a aceitação da dignidade, da autonomia e da diferença em cada um. Essa afirmação está sendo posta em âmbito geral. Ou seja, a concepção de que todo e qualquer ser humano é igual e é diferente. Entretanto, olhada em sua individualidade, a diferença 
posta como dois polos, masculino e feminino, assume nuanças e especificidades nos modos de ser de cada um. Do ponto de vista da natureza "[...] podem se manifestar dosagens particulares de hormônios, distúrbios da natureza gonádica (ovários e testículos) e também na fenotípica, órgãos da reprodução, por exemplo" (ALES BELLO, 2017, p. 77). Nestes casos, também, a visão de ser humano é mantida, digna de ser respeitada em sua autonomia e sua diferença. Isso porque a

Polaridade é indicada como ponto de referência em biologia, em medicina e,
consequentemente no direito. Por reconhecer a ambiguidade em alguns
sujeitos quanto à determinação sexual do ponto de vista genético e
endocrinológico, procede-se com cautela ao se intervir cirurgicamente, o que,
aparentemente poderia resolver essa ambiguidade, porque a orientação sexual
guarda toda uma complexa estrutura humana, diria Stein, e se poderia enganar
em uma direção diversa daquela escolhida (ALES BELLO, 2017, p. 77).

A polaridade aludida deve ser entendida como genético-dinâmica e qualitativaexperiencial. As vivências de cada pessoa, que se dão em contextos socioculturais junto ao outro influenciam e, muitas vezes, impõem-se às escolhas de vida. Os atos vivenciais de cada pessoa não são previsíveis, porque a subjetividade é algo único, que não se repete. Conforme Ales Bello (2017, p. 65) diz ao citar Stein, há um núcleo da personalidade que se manifesta no desenvolvimento da pessoa empírica, tornando-a uma pessoa unitária, com qualidades individuais a exemplo de um eixo em torno do qual a pessoa realiza, em sua subjetividade, seus movimentos de ser.

A subjetividade não é fechada em si, porém vai sendo constituída junto ao mundovida em que o outro está presente. Em suas vivências, o corpo-próprio experiencia o mundo externo com seus órgãos sensoriais via percepção e empatia. Se o mundo externo, tomado em seus aspectos naturais, é passível de ser compreendido pelos sentidos e pela percepção, a compreensão do outro é dada principalmente na empatia, chamada de entropatia na fenomenologia, à proporção que o corpo-próprio reconhece, de modo imediato, no corpo-próprio do outro, um corpo-vivente animado que por sua vez sente, manifesta emoções, toma posições, escolhe; isto é, um corpo-próprio que também é constituído, como ele mesmo, pelo físico-psíquico-espiritual. É neste estar-com o outro que a percepção de si como igual e como diferente do outro vai se realizando. E essa realização vai tomando os caminhos indicados por suas tendências pessoais, por suas escolhas, pelos modos de estar-com o outro, por situações vivenciadas muitas vezes sem terem sido escolhidas, mas que se apresentam a sua vida de modo contingencial. É nesse movimento de tornar-se (ou de vir-a-ser) que se dá no fluxo de sua vida, que a sexualidade de cada um vai se delineando e afirmando como modo de ser. 


\section{Os procedimentos que seguimos para realizar este estudo}

Para perseguir a pergunta por nós formulada, assumimos a postura filosóficafenomenológica, entendida como aquela que busca ir-às-coisas-mesmas. Coisas estas aqui tomadas como a descrição detalhada do filme de modo a obter-se um texto constituído por cenas e falas dos personagens. Esse texto é retomado para realizar a análise fenomenológica, tendo o filme em sua dinâmica plástica como pano de fundo.

Nossa proposta é apresentar uma leitura fenomenológica do filme entendida como um modo de olhá-lo e estudá-lo. Entendendo ser este um modo possível de compreender o filme, iniciamos o artigo com uma descrição sucinta de A Pele que Habito, visando situar o leitor/a; trouxemos referência e explicitação de pequenos resumos, artigos e resenhas mostrando a multiplicidade de olhares e compreensões possíveis sobre a película; neste processo, entendemos que tais publicações (como o presente artigo, inclusive) não trazem uma verdade sobre os sentidos e significados expressos. Para explicitar a perspectiva a partir da qual estamos olhando as questões centrais do tema tratado no filme, trouxemos uma exposição de concepções sobre o ser humano e sexualidade do ponto de vista da Antropologia Dual, tal como dela trata Ales Bello (2017), apresentando o solo em que o sentido de nosso estudo se faz para nós. Apresentamos os procedimentos de análise fenomenológica que realizamos, as interpretações das análises e uma síntese compreensiva, buscando dar conta do que é indagado por nós.

Para proceder com a análise do filme, em primeiro lugar as pesquisadoras assistiram juntas a ele, que já era conhecido por ambas. Na sequencia, realizamos um trabalho minucioso de transcrição do filme em $\operatorname{cenas}^{10}$, com suas nuances, expressões, frases e diálogos. O filme foi então dividido em 49 cenas. As duas pesquisadoras, individualmente, salientaram os sentidos possíveis (a pesquisadora $A$ levantou 244 e a pesquisadora $B$ levantou 233) que, para elas, destacaram-se em cada cena. A partir desses sentidos, cada pesquisadora, também individualmente, levantou unidades de sentido (US), que foram agrupadas e organizadas em núcleos de convergência. Para cada US foram identificadas e explicitadas hermeneuticamente as palavras ou expressões que apresentavam um sentido próprio na compreensão do texto. A pesquisadora $\boldsymbol{A}$ encontrou

\footnotetext{
${ }^{10}$ Neste artigo não traremos essa descrição, tendo em vista o espaço de que dispomos na Revista Pesquisa Qualitativa. Porém, para situar o leitor, indicaremos o momento em que a cena aprece no filme informando hora e minutos entre parênteses.
} 
17 núcleos de convergência e a pesquisadora $B$ encontrou 18 , fato que aponta para a congruência dos achados. Estes núcleos de convergência foram então entrelaçados para que se articulassem núcleos de sentidos.

Exemplo:

US 8: Na cena 4 (00h07min), Robert percebe que Vera/Vicente tem cortes nos pulsos, seios e barriga. Ele a toma nos braços e a leva para uma sala de cirurgia, onde cuida dos seus ferimentos. Ela respira intensamente, e ele pede que respire de forma mais suave.

Ela retorque: Se quiser que eu pare de respirar, mate-me.

Ele: Não fale besteiras.

Ela: Quanto vai durar tudo isto?

Ele: Tem a pele mais macia do que eu pensava...

Enxerto hermenêutico (USG): relações objetificantes, ela fala de aspectos fundamentais da existência (respiração e morrer), ele fala da pele (do corpo) como um objeto de atenção e uso.

Núcleo de convergência: Modos de ser-com.

As US constituídas na primeira etapa da análise, a etapa ideográfica (BICUDO, 2011), constituíram as unidades de significado (USG). Prosseguindo com a análise dos dados produzidos, passamos à análise nomotética (BICUDO, 2011), e as USG foram interpretadas pelas pesquisadoras separadamente, constituindo 35 Convergências de Sentido e Significado (CSS).

Exemplo:

USG 21: Quando Vicente/Vera questiona Robert sobre o que fará com ela depois de terminada e ele se irrita, entende-se que o cientista percebe que seu projeto de futuro estaria ameaçado a partir do momento em que ela estivesse terminada.

CSS: Projeto existencial

Continuando com a análise, no entrelaçamento dos núcleos de convergência de sentido e significado, constituíram-se 10 Ideias Nucleares (IN), expostas a seguir:

1. Modos de sentir/agir: sentimentos/preocupação; uso de drogas/atitudes ilícitas.

2. Cenário científico, ética/modelo explicativo: bioética; cuidados cirúrgicos; aspectos de saúde mental.

3. A sexualidade: violência, estupro, virgindade, vagina.

4. Projeto existencial: mudança não intencional de sexo; busca de projeto; o 
projeto de Robert mudando de rumo.

5. Modos de ser-com: modos de controle, dominação, opressão, imposição; segredos e prisões; estabelecimento confiança/intimidade; desencontro de mundos.

6. Espaço entre a vida e a morte: intenção e tentativa de suicídio.

7. Modos de transformação do corpo. Gênero/feminino/masculino: a unidade Vera/Vicente ou Vicente/Vera; rosto como identidade; a pele que envolve o corpo-vivente/corpo vivente; sentidos constituindo a percepção do corpovivente de mulher; modos de ser homem de Vicente; percebendo-se e assumindo-se como mulher.

8. Temporalidade e Espacialidade

9. Clima de suspense/terror: indícios de desfecho traumático.

10. Referência a arte/plasticidade do filme: ambiente da casa.

Ao nos concentrarmos na pergunta norteadora, "Como o corpo-vivente vivencia experiências que vão constituindo as modificações no modo de serlaparecer de uma pessoa do sexo masculino como uma pessoa do sexo feminino?" entendemos que devemos nos concentrar nas INs que dizem do perguntado. Entendemos que são sete INs que nos conduzem a dizer do modo de o corpo-vivente vivenciar as experiências que, na temporalidade vivida, vão constituindo os modos de ser/aparecer de um corpo-próprio, o de Vincent/Vera, nas modificações ocorridas: modos de sentir/agir, a sexualidade, projeto existencial, modos de estar-com, espaço entre a vida e a morte, modos de transformação do corpo, gênero/feminino/masculino, o temporal e o espacial.

As INs são interpretadas, sendo, neste movimento, trazidos outros dados elucidativos, como trechos da transcrição, alguns diálogos registrados e referências de autores que trabalham com os temas que se entrelaçam no estudo. Após a interpretação das INs, segue-se uma síntese compreensiva, com um movimento de metacompreensão para que haja um aprofundamento na reflexão sobre o que se evidenciou, retomando a busca pelo sentido que traz o compartilhamento do vivido (real e ficção), propiciando possibilidades de novas compreensões acerca do fenômeno inquirido. 


\section{A análise, as convergências de sentido e as interpretações das convergências}

Neste item vamos trazer as INs que, conforme nosso entendimento, dizem da pergunta por nós formulada. Como já mencionamos neste artigo, A Pele que Habito é um filme complexo, belíssimo e abre-se a diferentes possibilidades de ser olhado e interpretado. Portanto, ainda que sejam muito significativas e possibilitem análise e interpretação importantes, não consideramos as INs: Cenário científico, ética/modelo explicativo: bioética, cuidados cirúrgicos, aspectos de saúde mental; Clima de suspense/terror: indícios de desfecho traumático e referência a arte/plasticidade do filme: ambiente da casa.

Com esses esclarecimentos, trazemos as interpretações que realizamos sobre as INs indicadas. As interpretações são um exercício rigoroso do pensar das pesquisadoras que dialogam com a pergunta formulada, com as US destacadas na descrição das cenas do filme, com autores que tratam de temas que se mostram nas INs tratadas, principalmente da perspectiva fenomenológica.

\subsection{Os modos de sentir/agir}

\subsubsection{Vicente}

Comecemos por Vicente como Vicente, jovem de atitudes próprias de seu grupo e atos inconsequentes, como o uso recreativo de drogas e álcool para potencializar o fervor da juventude. Na cena 20 (01h02min), Vicente é apresentado ao público e o diálogo aponta para um jovem insatisfeito em seu lugar (sobre Vicente e seu mundo). Sob o efeito tóxico dessas substâncias encontra-se com Norma, ou melhor, desencontra-se com ela. Uma relação permeada por distorções de percepção leva-os a um ato sexual desajeitado, sem consentimento explícito, que parece um abuso, um estupro devido à agressividade misturada com volúpia e desejo. A dúvida sobre o estupro é causada por uma atitude de "cuidado" que Vicente tem com Norma, vestindo a roupa nela antes de ir embora. Na cena 19 (00h54min), ele a veste e sai com a moto, houve um certo cuidado, questionável.

Vicente é sequestrado e passa por todo o terror de prisioneiro em um cativeiro. Pede socorro, desespera-se. A solidão e o desconhecimento dos motivos pelos quais está ali são o foco de maior aflição. Em muitos momentos ele suplica a seu algoz, obedecendo, para que sua situação fique mais confortável e apelando para um sentimento fraterno; mas 
não tem jeito, é vítima, está vulnerável. Na cena 22 (1h04min), Vicente está no cativeiro.

\subsubsection{Vicente/Vera}

A partir da vulnerabilidade de um prisioneiro, Vicente foi transformado em Vera. Passa pelos horrores do assujeitamento, a aflição da impotência até chegar à resignação, mostrando certa passividade como expressão daquilo que não se pode modificar. Como nas fases do luto, Vicente sente muita raiva, fúria e braveza, durante a não aceitação e a negação de sua nova condição, imposta pelo mundo. A fúria se revela na cena 4 (00h07min), quando Vicente/Vera, ao mutilar os seios que tomam seu corpo, repudia o corpo feminino, denotando que esse não era seu projeto. No episódio do primeiro estupro simbólico, cena $32(01 \mathrm{~h} 21 \mathrm{~min})$, quando tem que manter o orifício da vagina aberto com dilatadores de vários tamanhos, Vicente/Vera se assusta, mas se resigna e obedece. A exploração do novo corpo revela-se na cena 31 (01h20min): o início da familiaridade com o novo corpo (quando se arrisca a olhar-se no espelho). A partir da aceitação, revela criatividade para reagir e não morrer existencialmente, como na cena 40 (01h34min): a concretude da escrita na parede traz a sensação da vida que permanece, quando Vicente/Vera escreve na parede respiro, sei que respiro. Ele/ela pratica ioga de modo disciplinado para garantir, vivenciando sua corporalidade, a consciência de si.

Cena 39 (01h33min): Da TV e dos livros retira sua sobrevivência, mantém a existência (copiando esculturas), consegue iniciar um novo projeto.

No episódio do segundo estupro, cometido por Zeca, Vincent/Vera descobre o poder da vagina e começa a usá-la para ganhar liberdade, apesar da vulnerabilidade e do medo que persistem. Começa, então, a aproximação afetiva com seu algoz (Robert). Jurando-lhe cumplicidade e fidelidade, consegue seu amor, expresso como desejo, inicialmente. O ápice da relação dos dois se dá em uma relação sexual, quando Vicente sente uma mistura de prazer e dor. Mas na dor mora a coragem, ele mata seu algoz; não com frieza, mas com nervosismo e lágrimas nos olhos.

Cena 46 (01h44min): Quando Vicente/Vera beija sua foto no jornal, vê-se que não abandonou seu eu. 


\subsubsection{Robert}

Robert é o protagonista da história, aquele que dá o tom do enredo. Entre os personagens, Robert é quem apresenta maior alternância de caráter durante a trama.

Cena 39 (01h33min): As emoções não têm lugar, Robert não quer falar sobre Normita; alternância de caráter da personagem; ora frio, ora meigo, ao acariciar o ombro de Marilia, consolando-a.

Passa de uma frieza congelante a pequenas demonstrações de afeto positivo. Apesar de parecer o dono da trama, no controle total da história e de seus planos, é o personagem que mais expressa sentimentos opostos e condutas antagônicas. Demonstrou grande resignação no evento da traição de Gal com Zeca, ao cuidar dela dia e noite. Seria amor ou já iniciava um projeto de vingança?

Difícil pensar que um sujeito como Robert, praticante de atrocidades com o outro, pudesse amar alguém. Um sujeito meticuloso, muito detalhista e cuidadoso nas suas manipulações científicas e cirúrgicas no corpo de Vicente, obcecado por seu projeto de vingança e pelo seu experimento de pele artificial, uniu ambos na construção de uma mulher que se submeteria a ele. Sentimentos de poder e controle permeiam sua ação. Já em relação a sua criatura, passa por momentos de admiração, iniciada com um olhar narcísico, o qual deriva para uma aproximação afetiva, em um movimento de sedução.

Cena 6 (00h17min): a obsessão de Robert ao olhar, embevecido, para Vicente/Vera.

Cena 15 (00h44min): clima de romance, a relação sexual, o respeito, o afeto e a cumplicidade fazem pensar que são um casal normal; morre por causa de seus sentimentos.

Quando Robert fala que Vicente/Vera agora tem a melhor pele do mundo, parece iniciar-se uma aproximação afetiva; Vicente/Vera retribui com gesto de fidelidade. Iniciase uma sedução sexualizada. Começa um jogo de poder pela admiração/sedução. Ao deparar-se com sua criatura exposta ao perigo (causado por Zeca), Robert passa a sentir um sentimento de proteção (talvez narcísico também), o qual dá lugar a um afeto mais positivo. Apesar de sua desconfiança e dúvida, deixa-se levar pelo feminino, com certa ternura. No ápice da relação sexual consentida entre os dois, Robert sucumbe, sai do estado de distanciamento e frieza, abrindo uma brecha à preocupação com o outro; ao ver Vera com expressão de dor, para, mostrando respeito e, talvez, amor.

Cena 16 (00h46min): a única cena do filme na qual ele aparece 
em uma situação social de normalidade e alegria; houve um descuido de Robert (ele abriu a guarda da existência) e perdeu Normita de vista na festa.

Na relação de Robert com a filha (Norma/Normita) e a mãe/governanta (Marilia), aparecem sentimentos positivos adicionais, incluindo momentos de normalidade em família. No âmbito social, Robert aparece sorrindo com alegria.

Mas a contingência não o deixa prolongar estes momentos atravessados por acontecimentos traumáticos ou perversos. Robert foi descuidado com a filha; falhou ao proteger todas as suas mulheres; Gal é atraída por Zeca e sofre um acidente que a leva à morte; Norma é atraída e estuprada por Vicente; Vera é estuprada por Zeca; Marilia sofre violência de Zeca, apesar do esforço de Robert para ter controle sobre o outro. Nesses momentos ele cai em desespero, revelando sentimentos genuínos, apesar de suas ações $a$ posteriori voltarem a ser frias. Com a morte da filha, fica perturbado e sofre, revelando indignação, tristeza e dor.

Cena 24 (01h07min): para Norma, foi seu pai que abusou dela; aparece o afeto e a indignação de Robert, tristeza.

Da dor nasce a motivação para a vingança e, assim, emoções congruentes cedem à frieza; Robert retorna ao trabalho: seu projeto de mudança de sexo de Vicente.

\subsubsection{Marilia}

Marilia é a personagem mais congruente em seus sentimentos, mantendo-se na mesma tonalidade afetiva do início ao fim da trama. Revela uma mistura de sentimentos ao ter que escolher, simbolicamente, entre os dois filhos no episódio em que Robert e Zeca se enfrentam. Os sentimentos de Marilia a induzem a pedir que Robert mate Vicente/Vera e Zeca. Aqui, finalmente, aparece o afeto positivo de Robert, após matar Zeca e salvar Vera. Marilia mantém uma lucidez racional ao longo da história, tenta alertar a todos sobre os perigos que correm tanto com o outro como consigo próprios. Revela desespero em relação aos filhos. Tem um sentimento familiar de pertencimento na relação com Robert e Normita, sente saudades, chora, demonstra carinho, mas sempre desconfiada.

Cena 41 (01h36min): Desconfiança de Marilia, que aparece como a personagem mais lúcida da história. 


\subsubsection{Norma}

Aparece na infância, brincando e cantando uma música em português e, quando sua mãe despenca em suicídio sobre sua brincadeira, grita assustada, congelada. Aparece novamente adolescente em uma festa, desambientada, pois passou muito tempo internada em clínica psiquiátrica devido a uma fobia social. Suas roupas não combinam com o entorno, seus olhos expressam desconhecimento da situação, não entende a conversa dos jovens; interessa-se por Vicente, paquera-o. Aceita os convites da turma e dele para se afastarem do salão sem questionamentos, indo para o jardim. Tem dificuldades com o corpo, com as roupas justas, com o salto da sandália. Tira a sandália e a blusa, em atitude infantilizada. Não reage às investidas sexuais de Vicente porque não entende a intenção do outro; aparenta desejo e medo, fica passiva, congelada, mas quando ele tenta iniciar o ato sexual, grita aterrorizada. Ele cobre a boca dela, para que pare de gritar; ela não entende e o morde; ele dá-lhe um tapa, e ela desmaia.

Cena 19 (00h54min): Volúpia, desejo, medo e agressividade no contato de Vicente e Norma; houve certo cuidado, questionável, da parte de Vicente quando colocou a roupa em Norma.

Seu pai a encontra e ela acorda com ele por cima dela. Grita desesperada. Aparece novamente no hospital psiquiátrico; pensa que seu pai abusou dela, com os olhos arregalados quando ele entra no quarto; ela se tranca no armário, recusando-o, com medo. Suicida-se na sequência; como sua mãe, pula da janela.

\subsubsection{Zeca}

Aparenta um desvio de saúde mental traduzido em tiques nervosos. De fala infantilizada, apresenta comportamentos bizarros e agressivos, frieza, insensibilidade. Tem um modo animalesco e primitivo de agir, destituído de ligação com o outro, com o passado ou com o futuro. Instala o terror.

Cena 8 (00h23min): aspectos ao mesmo tempo infantilizados $e$ agressivos, quando Zeca entra na trama; agressividade mesclada com infantilidade.

Cena 9 (O0h26min): comportamento bizarro quando Zeca lambe a tela do monitor; frieza para atingir os objetivos, insensibilidade ao imobilizar a própria mãe; vulnerabilidade de Vicente/Vera. 
Cena 10 (00h31min): agressividade e terror quando Zeca quase sufoca a mãe com um guardanapo; comportamento bizarro quando Zeca morde o rosto de Vicente/Vera/Gal de modo animalesco; Marilia assiste ao horror (estupro); mostra-se preocupada e intuitiva.

\subsection{A sexualidade}

Cena 10(00h31min): primeiro estupro; cena sexual com brutalidade, porém com uma pitada de sedução para atingir algum objetivo a posteriori; Confusão, estupro, dor, agressividade, brutalidade.

Na sexualidade está implicada a dimensão afetiva do ser-no-mundo. Há sempre um Dasein e um ente mundano que se entrelaçam pelo afeto, no sentido de afetação. $\mathrm{O}$ afeto nem sempre se dá entre Dasein e Dasein; pode dar-se em uma relação de utensílio. No estupro cometido por Zeca, a relação se dá por brutalidade, agressividade e animalidade. Alguns gestos remetem à sedução, como as lambidas, mas se misturam com asco e dor. $\mathrm{O}$ gesto sexual também tem, nesta cena, um poder de barganha dos dois lados. Zeca queria chantagear Robert com a dominação de Vera, e Vera/Gal/Vicente viu, neste entrelaçamento com o desejo de Zeca, uma possibilidade de fuga. Então ambos participam do ato, com suas intenções para além da sexualidade.

Cena 16(00h46min): segundo estupro; a posição dos corpos das personagens gera dúvida sobre o ocorrido; houve abuso?

Como a sexualidade não opera no vazio, nem é um solipsismo, esse entrelaçamento de mundos, distorcido por percepções tão distintas da coisa, como aconteceu com Vicente e Norma, levou-os a um ato equivocado. A intenção de ambos diferia do que realmente se deu no gesto final. Vicente olhou para Norma como outro corpo-vivente e objeto de desejo da sexualidade. Norma, perdida no espaço e na temporalidade, pouco acostumada com os códigos de conduta de seus pares/iguais, também olha para Vicente como corpo-vivente e objeto de desejo; no entanto, assusta-se com a aproximação física, desesperando-se com as investidas corporais de Vicente. Talvez seja possível dizer que ambos são inocentes, tanto no ato, como em seus intentos; no entanto, as ações tomam um curso que se abre para a possibilidade do abuso, do estupro, de uma relação sexual mais selvagem (como os outros jovens da festa), para a 
não sensibilidade e a espera de Vicente. Isto é, a cena fica aberta a uma multiplicidade de significados. O desencontro de mundos parece apontar para uma relação junto a, não a uma relação de ser-com.

Cena 18 (O0h52min): Vicente tenta seduzir Cristina, que é homossexual; surgem questões de sexualidade e de orientação sexual; há um clima de sedução.

Questões de gênero permeiam todo o filme. Com Vicente, parece que ele, pelo discurso, testa possibilidades sexuais, o que abre para um entendimento de que talvez ele ainda não estivesse bem determinado com sua orientação sexual. Assim como a sexualidade, a sedução pode ser entendida, como em Merleau-Ponty (1999), como uma atmosfera colada na existência e constantemente presente no filme, misturada com cenas de horror.

Cena 31 (01h20min): terceiro estupro; Vicente/Vera deve manter aberto o novo orifício da vagina com dilatadores para que, pouco a pouco, fique mais profundo; o orifício da vagina representa a sexualidade comandando a existência, como energia vital, libido; além disso, o uso da vagina se dá como poder fundamental de existência; é uma cena de terror e de excitação, ao serem dispostos dilatadores em vários tamanhos para que o novo orifício não cicatrize.

Robert passa o comando para Vicente, ora recuperado da cirurgia, para manter aquele orifício aberto com os instrumentos. $\mathrm{O}$ ato aponta para o ser e para o corpo em uma relação de uso; Vincent/Vera deve fazê-lo com atenção, pois sua vida depende deste orifício, já que é por ele que respira. O terceiro estupro é simbólico. Pode-se considerar o ato um estupro, porque há uma invasão corporal que fere, machuca corpo e alma. A sexualidade comanda a existência, porque engajamos nela toda a nossa vida pessoal. Porque o fazemos? "Porque nosso corpo é, para nós, o espelho de nosso ser, senão porque ele é um eu natural, uma corrente de existência dada, de forma que nunca sabemos se as

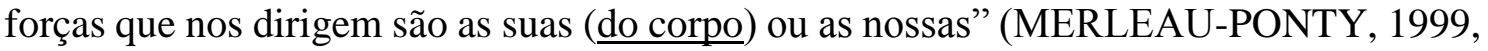
p.236, grifo das autoras). Para Merleau-Ponty, não existem reflexos sexuais, pois “[...] é preciso que exista, imanente à vida sexual, uma função que assegure seu desdobramento [...]. É preciso que exista um Eros ou uma Libido que animem um mundo original, dêem valor ou significação sexuais aos estímulos exteriores e esbocem, para cada sujeito, o uso que ele fará de seu corpo objetivo" (MERLEAU-PONTY, 1999, p. 215). 
Cena 32 (01h21min): Vicente não lembra o que fez com Norma, pois havia consumido drogas; permanece a dúvida de ter havido o abuso, ou não.

O modo como as personagens lidam com o corpo (Körper) na superficialidade e no abuso revela displicência também com o Leib.

Cena 42 (01h38min): cena romântica, quando Robert está seminu deitado sob lençóis e Vera/Vicente chega com a bandeja, vestida com uma camisa semiaberta; a sexualidade parece ter resolvido as coisas; Vicente/Vera entendeu o poder da vagina (respiro, sei que respiro).

Aqui o elemento romântico aparece como pano de fundo para deflagrar, enfim, o mundo compartilhado, a familiaridade. A cena na cama, ele seminu sob os lençóis e ela trazendo algo na bandeja, desvela uma tonalidade afetiva de harmonia e entrosamento. Ela veste camisa entreaberta, sugerindo o clima sexual que precede o momento. A sexualidade resolveu os conflitos, mas também é pivô destes. O poder da sexualidade, aqui representada pela vagina, é tão essencial à existência humana, que pode ser colocada ao lado da respiração. "Existe osmose entre a sexualidade e a existência" (MERLEAUPONTY, 1999, p. 234).

Cena 43 (01h39min): Robert, cirurgião plástico, todo-poderoso capaz de qualquer atrocidade contra o outro, é pego pelo poder da vagina/mulher; em um lapso na iniquidade, Robert presta atenção no outro e sua dor, interrompe o ato sexual; Vera vai pegar o lubrificante, desce as escadas, entra no escritório, pega a arma na gaveta e a coloca na bolsa, com o lubrificante. Ao retornar, vê Robert animado; este senta-se na cama e diz: até que enfim, achei que tivesse partido; sim, Vera parte seu coração com tiros.

Toda a expressão sexual do filme é permeada por violência. Todo o poder pretendido pelo protagonista como algoz, controlador da história, do outro e dos corpos, desintegra-se quando ele se apaixona e sucumbe ao poder feminino. "Há uma compreensão erótica que não é da ordem do entendimento, já que o entendimento compreende percebendo uma experiência sob uma ideia, enquanto o desejo compreende cegamente, ligando um corpo a um corpo" (MERLEAU-PONTY, 1999, p. 217). Marilia tentou alertá-lo: sua obsessão/paixão se tornaria um câncer que o corroeria por dentro. 
Cena 46 (01h44min): cena sexual intensa consentida; uma possível questão de bissexualidade, pois Robert propõe sexo anal; clima de tensão/tesão.

O ápice da trama se dá em uma relação sexual intensa que mistura prazer e dor, abertura de possibilidades nas questões de escolha sexual: heterossexualidade, bissexualidade, homossexualidade. O suspense na cena aumenta o nível de tensão, que aumenta o nível de "tesão" de Robert ao esperar ansioso pelo retorno de Vera ao coito interrompido. Assim como em Freud, para Merleau-Ponty

[...] o sexual não é o genital, a vida sexual não é um simples efeito de processos dos quais os órgãos genitais são o lugar, a libido não é um instinto, quer dizer, uma atividade naturalmente orientada a fins determinados, ela é o poder geral que o sujeito psicofísico tem de aderir a diferentes ambientes, de fixar-se por diferentes experiências, de adquirir estruturas de conduta. É a sexualidade que faz com que um homem tenha uma história. Se a história sexual de um homem oferece a chave de sua vida, é porque na sexualidade do homem projeta-se sua maneira de ser a respeito do mundo, quer dizer, a respeito do tempo e a respeito dos outros homens (MERLEAU-PONTY, 1999, p. 219).

Esta é a história de Robert.

\subsection{O projeto existencial}

\subsubsection{O projeto de Vicente}

Vicente aparece como um rapaz muito jovem que ainda não se encontrou; evidenciava ter dúvidas sobre sua orientação sexual, como na cena 18 (00h52min), quando conversa com Cristina, a vendedora da loja da mãe dele. Cristina é homossexual, mas ele tenta seduzi-la a usar um vestido de que ele gosta, para sair com ele. Surgem questões de sexualidade e orientação sexual; há um clima de sedução. Dada a sua juventude, na trajetória de sua vida não havia ainda realizado escolhas que fossem delineando seu estilo de vida e seu modo de ser, tendo se tornado um bom alvo para o projeto de Robert. A aparência de pouca idade de Vicente induz Fulgencio, o cirurgião colega de Robert, a suspeitar de escolha tão invasiva e definitiva relativa à mudança de sexo, por alguém tão jovem; questiona a possibilidade de uma pessoa tão jovem ter reais condições de fazer escolha deste tipo. Indica entendimento subjacente às cenas explícitas e faladas, o de que uma escolha deste porte solicita análise e reflexão da pessoa sobre si, sobre a qualidade de vida que vem vivendo e sobre como quer viver após a cirurgia transformadora. 
Cena 29 (01h16min): alguém suspeita da condição jovem da pessoa que quer uma cirurgia confidencial e definitiva (um colega médico, antes da cirurgia de Vicente, desconfia de seu projeto, já que este é muito jovem).

Vicente não tinha, em seu campo fenomenal, um projeto de mudança de sexo. Foi lançado em uma situação em que não the foi dada a possibilidade de escolher. Foi dopado e submetido a uma vaginoplastia, a primeira cirurgia transgenital. Foi transformado em Vera à revelia. Durante esta transformação, tentou lutar, tentou fugir, resignou-se, ficou passivo, mas sempre mostrou claramente que ser mulher não era seu projeto existencial.

Cena 4 (00h07min): Vicente/Vera, ao mutilar os seios que tomam seu corpo, repudia ao corpo feminino, denotando que este não era seu projeto; os seios mutilados e o pescoço cortado revelam uma tentativa de atacar o projeto de Robert, que estava concentrado em construir uma mulher segundo um ideal de beleza, com pele perfeita.

A automutilação nos seios, além de expressar toda a dor, angústia e impossibilidade de Vicente resolver o conflito de outra maneira, revela também repúdio ao corpo feminino. Além disto, parece que Vicente queria destruir o projeto assumido por Robert com extrema obsessão, uma vez que cortar e ferir uma pele perfeita significa estragá-la. Vicente é lançado ao mundo como Vera, já tendo constituído modos de agir durante sua temporalidade com um corpo que não era seu corpo original; um corpo estranho, não escolhido, que, contudo, foi-lhe dado como facticidade. Esta temporalidade expõe a contingência mundana à qual estamos sujeitos. Vicente é transformado em mulher e não tem como voltar atrás. A mutilação sofrida por Vicente traz o desespero de ficar sem uma parte identitária de seu corpo para exercer seu projeto existencial de ser homem, via sexualidade/genitalidade. Vicente se afasta, assustado com a vivência do novo por ele não buscado, vivência esta que é fruto da mudança não intencional de sexo, a qual deveria ser produto de uma escolha analisada e refletida.

Cena 32 (01h21min): mesmo com o corpo já transformado e induzindo a cicatrização do orifício vaginal com dilatadores, Vicente obedece, ainda na esperança de retorno a sua antiga vida; tenta manter seu projeto existencial.

A Vicente restava começar a se familiarizar com seu novo corpo, formado com próteses e órgãos estranhos acrescentados (como os seios, por exemplo), ou substituindo 
outros, como a vagina, pedaço traduzido em vazio, revelador da ausência do pênis.

Cena 31 (01h20min): o início da familiaridade com o novo corpo, quando se arrisca a olhar no espelho.

A exemplo do cuidado dispensado a um machucado, Vicente cuida daquele novo corpo, daquele novo orifício, daquele novo vazio que teria de ser preenchido com um novo projeto existencial. A esperança de retomar sua posição de sujeito de sua história faz com que Vicente não abandone seu projeto de retornar a sua casa. Mesmo com o corpo já transformado e cuidando da cicatrização do orifício vaginal com dilatadores, Vicente obedece a seu algoz, ainda na esperança de retorno a sua antiga vida; tenta manter seu projeto existencial.

Cena 37 (01h30min): a não aceitação, a recusa de sua nova condição continua; devolve o livro de maquiagem e as pinturas; arranja formas diversificadas para lidar com sua atual situação (usa os lápis de maquiagem para escrever e desenhar na parede, faz uma contagem do tempo, comum nos presídios).

Vicente, agora batizado Vera, a princípio recusa o novo nome, vira o rosto. Um nome diz do símbolo da identidade da pessoa. Inicialmente, trocar de nome parece difícil para Vicente, porque ele não escolheu sua mudança sexual, nem o nome que lhe fora atribuído.

\subsubsection{O projeto de Vera}

Cena 35 (01h28min): o nascimento oficial; o batismo, quando

Vicente recebe o nome de Vera; a princípio, não o aceita.

Causa estranhamento a mudança de nome assistida no filme, a decisão de Robert de chamar sua criatura de Vera foi uma imposição unilateral. A dificuldade de, repentinamente, mudar o nome do/a personagem foi por nós sentida na própria descrição do filme. De quem estávamos falando: Vicente ou Vera? Em muitas passagens, talvez em função da percepção do dual se manifestando, falamos em Vicente/Vera.

Vicente, em sua transformação de homem em mulher, parece viver as fases do luto da morte de seu projeto de ser homem; não aceitação de sua condição atual; raiva, fúria.

Cena 36 (01h29min): continua a não aceitação; a raiva, a fúria de sua nova condição (ao rasgar ferozmente os vestidos que lhe 
trouxeram); por vezes tentou barganhar com Robert, depois com Zeca; então a resignação, até a aparente aceitação, no final.

Cena 41 (01h36min): a aceitação, quando Vicente/Vera aparece em roupas femininas e maquiada.

A pessoa em fase de negação e raiva não tem criatividade para encontrar novas formas para solucionar seu conflito. Quando Vicente sai deste movimento, da atmosfera existencial de ira e começa a dar-se conta de suas dores, seus anseios, os dias passados em cativeiro (registrados nas paredes de seu quarto), evidencia ele estar se assumindo, reconhecendo-se no corpo-próprio que o liga ao mundo e liga o mundo a ele. São indícios de estar se abrindo a caminhos possíveis de modos de ser e existir.

Cena 40 (01h34min): a concretude da escrita na parede traz a sensação da vida que permanece, quando Vicente/Vera escreve "respiro, sei que respiro"; verbaliza o dar-se conta de que vive pela percepção de funções básicas de seu corpo-próprio.

Quando Vicente inaugura um novo projeto existencial, mediado pela arte e pela ioga, passa a existir novamente como pessoa singular; tem algo que é só seu, apesar de continuar prisioneiro na fisicalidade da situação, cativo de seu algoz. A filosofia da ioga, exposta no programa de TV a que ele assiste, diz que a prática desses exercícios traz liberdade existencial, inaugura um lugar, faz retomar o contato com o Eu interior. Ele busca isso. A arte, com os livros e cenas da TV em que apareciam esculturas de corpos ou partes dele, traz a reconstrução do corpo-próprio (Leib). Ao modelar um corpo de escultura, Vicente/Vera simbolicamente modela a si mesmo; neste momento consegue se localizar na temporalidade, ou seja, entra novamente na história. Em seu ensaio arte $e$ existência, Pompéia (2014) fala da arte como algo próprio do humano, aquilo que dá voz ao que ainda não foi iniciado, algo pode e pede para vir-a-ser. Neste chamamento, enquanto alguns são tocados pela obra, a existência é tocada pela arte. Apesar de parecer virtual ou imitação da realidade, a arte contém uma verdade, não no sentido lógico, mas na perspectiva afetiva. "Como no teatro, no meio de uma situação em que tudo é mentira, ali onde tudo é falso, o verdadeiro também se manifesta. E o faz sem a mediação de um processo racional; coloca-se de uma forma muito particular, muito imediata e extremamente efetiva" (POMPÉIA, 2014, p.20). O ambiente onde Vicente/Vera estava e tudo o que lhe ocorrera parecia uma mentira; tudo era falso, como em uma vida paralela. Além disso, a obra de arte fala ao homem com um falar especial, e a voz é a do próprio autor. No momento em que a obra toca alguém, há uma união, uma intimidade que traz a 
recordação do aconchego. "É um momento de encantamento, em que nossa existência suporta os desdobramentos daquilo que pode ser e que se realiza através da fala silenciosa, oculta e misteriosa das coisas do mundo" (POMPÉIA, 2014, p.26). A arte faz crescer o homem, propicia o reencontro com outros homens e as coisas do mundo. No caso de Vicente/Vera, a escultura, uma massa sem forma, um pedaço de argila da terra assume forma de busto e faz nascer um novo homem/mulher; uma pessoa pode se modelar ali.

Em todo o enredo vê-se que Vicente não desiste de si mesmo, de voltar para casa, onde reside o singular. Ele vê em cada personagem que entra na trama uma possibilidade de escape, como no momento em que o colega de Robert suspeitou da cirurgia sem consentimento, e se assume mulher, por vontade própria.

Cena 45 (01h42min): a atitude de Vicente/Vera faz com que Robert acredite definitivamente nela, em sua aceitação, cumplicidade, talvez amor, ao assumir que fez a cirurgia por vontade própria para salvar Robert das desconfianças do colega.

O desfecho (POMPÉIA, 2014), não significa que algo se acabou; ao contrário; des-fecho significa tirar o fecho, isto é, abrir. Algo se inicia: a chegada da mulher Vera em Vicente, apesar de parecer um plano para acabar com Robert. Vicente encarna a mulher Vera, não apenas no corpo (Korper), como também no corpo-próprio (Leib).

Neste momento Vicente faz uma proposta a Robert: viverem juntos, conviverem, dando indícios de querer instaurar um novo projeto de vida. A cena 42 (01h38min) é familiar e, em um clima de romance, Vera leva o café da manhã a Robert na cama. Fazem uma promessa: ele a deixaria livre, e ela nunca o abandonaria.

Aqui vemos que Vicente aceitou o novo corpo, apesar do processo de horror e atravessamento pelo qual passou, mas não abandonou a percepção de si constituída na historicidade de sua vida. A promessa era um blefe para matar Robert e voltar para casa. Vicente, finalmente retorna à sua vida, como Vera.

Cena 49 (01h49min): o vivido por Vicente antes de todo o terror; finalmente, Vicente retoma seu lugar, seu nome, toma posse do seu Eu (última fala do filme).

\subsubsection{O projeto de Robert}

O projeto existencial de Robert Ledgard, cirurgião plástico de sucesso, parecia um plano de perfeição: atingir o corpo perfeito, a pele perfeita, a vida amorosa perfeita. Em 
seu projeto de vida, após o acidente sofrido por sua esposa, quando esta sofre queimaduras em grande parte do corpo e quase morrendo em virtude, Robert passou a desenvolver uma pele artificial perfeita, que não queimasse. Iniciou com experimentos usando matériaprima animal (porco); porém, logo passou a usar matéria-prima humana. A cena 3 (00h05min) deixa implícito que ele buscava sangue em uma maternidade. Para além da questão da bioética e sua crítica que o filme explicita, o Dr. Robert usa o corpo do humano e seus derivados de modo objetal. Passa a realizar seus experimentos em Vicente, justificado, até certo ponto, pela fome de vingança, uma vez que o rapaz estuprou sua filha, que depois se suicidou. Realiza a cirurgia de mudança de sexo de Vicente, com ajuda de colegas, sem o consentimento - e sequer o conhecimento - de Vicente, sem que os colegas saibam da ilegalidade da ação.

Cena 29 (01h16min): passam rapidamente pela antessala de cirurgia, olham os papéis de modo displicente; parece que não dão muita atenção aos aspectos burocráticos que garantiriam a ética do experimento.

Em todo o enredo Robert é guiado pelo passado, por suas perdas (da esposa, para a traição com Zeca e então para o suicídio; da filha, para o suicídio), pelas mágoas (de seu irmão Zeca), pelo desejo de vingança (pelo suposto estupro da filha).

Embora Robert domine o ambiente e todos a sua volta, sempre falha em seu projeto afetivo. É fraco para proteger seus afetos das mazelas mundanas; é sempre roubado por outro homem.

Cena 24 (01h07min): Robert não conseguiu proteger sua filha de um estupro; não protegeu sua mulher, que se queimou; não protegeu Vera do estupro (apesar de trancá-la e deixá-la isolada do mundo e de todos); todo o controle (até o científico) que julga ter não é eficiente; perde seus amores e a si mesmo; ao longo da trama, seu projeto muda de rumo, quando entra na história Zeca, que estupra Vera/Vicente e estraga seu experimento/brinquedo.

Ao saber que o experimento está terminado e que seu corpo de mulher é visto como perfeito, Vicente/Vera questiona seu algoz sobre o futuro, enquanto projeto, fato este que perturba Robert.

Cena 6(00h17min): quando Vicente/Vera questiona Robert sobre o que fará com ela depois de terminada e este se irrita, entendese que o projeto de futuro do cirurgião estaria ameaçado, no 
momento em que Vicente/Vera fica completa.

Mas Robert não se deu conta do movimento temporal, pois está preso a vieses, amarrado ao passado e a um projeto idealizado apenas por ele. Também Marilia lhe indaga sobre o que acontecerá ao fim do experimento, mas ele não quer falar sobre o assunto. É ela que indica um caminho, que visualiza como o único viável para a sobrevivência de Robert: ele terá que matar Vera, ou escondê-la pelo resto da vida.

Quando Vera está terminada e nasce um novo ser, Vicente totalmente encarnado em Vera, o projeto de Robert parece acabado. O cirurgião conseguira esculpir um corpo primoroso, uma pele perfeita, uma mulher à semelhança de sua esposa, como se a trouxesse de volta, apaixonada. Mas como um projeto existencial só acaba com a morte, Robert não consegue um bom desfecho. Como diria Pompéia (2014), um bom desfecho abre para novas possibilidades de existir. Como o desfecho tem a ver com a totalidade da história, é como um ciclo que se encerra para que novos enredos e tramas possam surgir. Robert queria congelar o tempo, coagular as pessoas; não ultrapassava na existência, manteve-se, em seus atos do presente, comandado pelo passado sem se dar conta de que todo o seu projeto existencial estava amarrado ao experimento inicial da pele artificial, o qual lhe permitiria salvar a esposa que o havia traído, resgatá-la do fogo. Depois, preso na vingança, vinculou seu projeto existencial ao experimento em Vicente. Quando o experimento acabou, simbolicamente só lhe restou a morte, ou viver o passado novamente com a esposa, agora na forma de Vera; não inaugurou um novo projeto.

\subsubsection{O projeto de Marilia}

A partir do projeto de Robert, fora da ética, imoral, ilícito, todos a seu redor acabam prisioneiros de seu destino.

Cena 8 (00h23min): quando Marilia pergunta a Zeca como os encontrou, fica claro que todos são prisioneiros de seus destinos, têm que esconder-se; também ela é prisioneira de suas escolhas, pois está proibida de receber visitas.

Marilia engajava-se no projeto do filho de sucesso, a ponto de banir o outro filho de suas vidas.

Cena 9 (00h26min): Marilia tenta proteger o projeto de Robert, quando Zeca invade a casa.

Marilia alerta Robert sobre as possibilidades futuras, mas ele não lhe dá ouvidos. 
O projeto de Zeca aparece ligado ao projeto de Marilia e de Robert. Zeca quer que Robert, que é cirurgião plástico, transfigure o seu rosto, o que lhe facilitaria fugir da polícia. Seu projeto consiste em escapar de qualquer responsabilidade sobre os próprios atos. Zeca se mostra presentificado ${ }^{11}$, seus atos são animalescos; tem dificuldade de articular o passado com o presente; não há futuro, não há projeto.

O projeto de todos os personagens é atravessado por questões de saúde mental. Marilia justifica as insanidades, as atrocidades cometidas por seus dois filhos com base na loucura de seus pais, como des-culpa ${ }^{12}$ (POMPÉIA, 2014). Aqui também aparece a referência ao feminino, como força, potência do ventre que carrega o destino. A cada novo nascimento há esperança; o destino da humanidade está no surgimento de novos seres.

Cena 12 (00h37min): o significado do ventre aparece quando Marilia conta sua história e a de seus dois filhos; diz carregar a loucura nas entranhas.

\subsubsection{O projeto comum}

$\mathrm{O}$ entrelaçamento dos personagens aponta para o entrelaçamento de destinos e projetos. Destino é definido como algo que não pode se dar de outro modo, como o serpara-a-morte. Fala também da ausência de limites, do corpo e do ser, em um movimento invasivo, o não reconhecimento da singularidade (pessoalidade) do outro. A confusão emocional torna-se uma confusão de lugares e papéis, de movimentos não identificatórios em que os gêneros masculino e feminino se misturam.

\subsection{Modos de ser-com}

Os modos de ser-com que se mostram na convivência entre Robert e Vicente/Vera são estabelecidos pelo controle, dominação e imposição de decisões sobre a vida do outro, sem que a este outro seja dada a possibilidade de escolha. Tal escolha é permeada por segredos e aprisionamentos, por desencontros de mundos nos quais os diálogos

\footnotetext{
${ }^{11} \mathrm{O}$ sujeito que vive apenas no presente, como um psicopata; o passado nada lhe ensina e no futuro nada lhe assusta, como vê-se em patologias, por exemplo.

12 É uma manobra para tirar o peso da responsabilidade do culpado. Marilia minimiza as atrocidades de seus filhos, colocando a culpa no pai de cada um.
} 
explicitados por palavras correntes que, em virtude de sua ambiguidade, dizem de intencionalidades diferenciadas, criando uma zona densa em que os sentidos não se evidenciam. Estes mundos são também explicitados em jogos em que a conquista da confiança se torna um alvo, que vai sendo alcançado em momentos de intimidade entre Robert e Vera.

Ser-com significa que se está com o outro, qualquer que seja, ser humano, natureza, ideias culturais, científicas, religiosas. Diz de uma união existencial, pois o hífen em ser-com indica que não há separação entre sujeito e mundo-vida, uma vez que o sujeito já é sempre no mundo, junto ao que está a sua volta, por ser corpo-vivente intencionalmente ${ }^{13}$ voltado para o que chama sua atenção e para o que se dispõe a fazer, tendo em vista a solicitação posta pelo próprio mundo e que o afeta. Em sua obra Ser e Tempo (1988) Martin Heidegger nos fala do ser-aí-no-mundo-com, onde o ser-aí significa o Dasein, que está aí no mundo, zona de abertura de possibilidades de acontecer. O seraí-no-mundo-com habita o mundo de modo familiarizado junto ao que vem a seu encontro na cotidianidade. Os seres com os quais se está no aí podem vir ao encontro do sujeito como um conjunto de utensílios que se permitem ser usados e manipulados, evidenciando um modo de ocupação. Podem, também, ser seres humanos que se doam ao sujeito, com quem se preocupam, buscando o que permitem as possibilidades deste sujeito, com os quais se preocupam. Neste caso, o cuidado para com o outro se impõe.

Robert toma Vicente como um utensílio para ser manuseado nas experiências que realiza. Mesmo sendo um corpo-próprio que intencionalmente se dirige ao mundo, Robert não o ouve nesse seu modo de ser. Na sua obsessão por criar um corpo (Körper) com pele perfeita e de acordo com sua ideia de beleza, ele permanece recorrentemente manipulando o corpo de Vicente até transformá-lo em Vera. Quando consegue essa transformação, no momento em que retira a máscara cirúrgica e vê o rosto criado, fica extasiado com sua criação e a batiza de um nome: Vera. Estas atitudes se evidenciam nas passagens descritas na cena 4, em que o cirurgião está ocupado, cuidando do corpo que havia sido danificado por um ato intencional de Vicente, o de por fim a sua vida, cortando-se. Ele concentra-se apenas na pele do corpo que ali está. O mesmo fica claro na cena 35, quando Robert retira a máscara do rosto de Vera.

\footnotetext{
${ }^{13} \mathrm{~A}$ intencionalidade é um conceito nuclear no pensamento fenomenológico. É um conceito complexo e difícil de ser trazido em uma exposição rápida. Mas pode ser entendido, em uma primeira visada, como um fio invisível que nos une ao que nos focamos mediante um olhar atento e interrogador. Trata-se de um modo de estarmos sempre atentos ao que nos envolve no mundo-vida circundante. Essa atentividade é, primeiramente, existencial e não intelectual.
} 
Cena 4 (00h07min): Enquanto Vicente/Vera fala de aspectos fundamentais da existência (respiração e morrer), Robert fala da pele (do corpo) como um objeto de atenção e uso.

Este cuidado com a obra, isto é, Vera, mostra-se em muitas cenas, em diferentes momentos da trama. Aos poucos Robert se revela pré-ocupando-se com Vera, ao expressar certa ternura por ela, como no momento em que a resgata do domínio de Zeca, que a está estuprando e machucando. Entretanto, é um cuidado que se manifesta, mesmo nesta cena, como um misto de cuidado e criação; a obra e o cuidado com Vera.

Cena 33 (01h23min): Robert diz que os seios de Vera são como gotas de cristal e fica embevecido com sua criação; pouco a pouco, o algoz vai se transformando em alguém "bonzinho”; a criação deve ser protegida.

Cena 34 (01h27min): Robert costura o pescoço de Vera e a salva; fala no plural pela primeira vez "tivemos sorte”; o plural já fala de algo que se constrói somente na relação (nostridade).

Robert controla Vicente desde o momento em que o rapta, aprisionando-o em um quarto sem luz, com limitada possibilidade de sobrevivência; a não ser que ele, o dominador, o alimente. Não se dirige a ele, não responde a suas perguntas. Mantém-se silencioso, sem explicitar o seu plano e o porquê de Vicente ser submetido a ele, como forma de vingança. Realiza uma vaginoplastia impondo a Vicente, sem lhe comunicar, a mudança de sexo. Com esse procedimento, decide sobre a vida do outro, sem se questionar, agindo de modo objetivo e frio, como um cientista que assume a postura de neutralidade e objetividade. O outro, em seu corpo-vivente, quer saber do projeto de vida em que se vê com ele.

Cena 6 (00h17min): manipulação do corpo como objeto concreto, manipulado pelo outro (presente no diálogo entre Vicente/Vera e Robert, quando ela pergunta se ainda há algo a ser melhorado e se ela está terminada); discutem sobre conviver, viver-com, em uma relação de ser-com.

Os modos de ser-com no âmbito da casa de Robert também são vivenciados como mudanças de atitudes autoritárias e de ternura, nas quais se evidenciam o apreço de Robert por Marilia e seu contentamento de vê-la em sua casa. Estes modos também ficam explícitos por distanciamento, como na ausência de Zeca, na proibição que Robert impõe à presença dele em sua casa e na de Marilia entrar no quarto de Vera. O núcleo familiar 
composto por Marilia, Zeca e Robert é constituído à base de segredos, traições e atitudes antiéticas.

Desencontros de mundos e a falta de sintonização de intenções subjacentes ao que é dito no diálogo são expostos na cena em que Vicente e Norma estão na festa de casamento e se apresentam. Estão em um grupo de jovens que vivem de acordo com os usos e costumes próprios: consumo de drogas e relações sexuais livres, por exemplo. Vicente faz parte deste grupo, Norma não. Ela é uma estranha ao grupo e, como tal, o estranha; está em processo de socialização. Ao saírem junto com os demais para o jardim, mantêm diálogo desconexo, como se falassem línguas diferentes; os significados das expressões são distintos, apesar de as palavras usadas serem as mesmas. Os sentidos dos atos são incompreensíveis um ao outro. Estabelece-se um equívoco, com consequências drásticas para a vida de ambos.

\subsection{Espaço entre a vida e a morte}

A cena 4 (00h04min) mostra Vicente/Vera cortando-se também nos pulsos. Esta é a primeira tentativa de suicídio no filme, a ser seguida por outras. O espaço entre a vida e a morte que se apresenta no filme nos fala de uma estadia limítrofe, um lugar de habitação do ser, o lugar de uma Instabilidade Perpétua (PESSANHA, 2009) que nos é dado pela trama como um lugar especial, de tensão e de sobrevivência. No entanto, é nosso lugar cotidiano de habitação, apesar de tentarmos, a todo o custo, preencher este espaço com atividades, ora muito importantes e condizentes com nosso projeto existencial, ora com superficialidades, para nos afastarmos da angústia do ser-para-amorte. As personagens habitam este lugar durante toda a trama, seja por meio da ideia do suicídio ou do assassinato. Como na cena 11 (00h36min), em que acontece o assassinato de Zeca.

Na cena 33 (01h23min) aparece a segunda tentativa de suicídio: por descuido de Robert, Vicente/Vera foge. Apesar de aparente resignação, sua esperança ainda não morreu; resta a força para lutar por sua vida, por sua dignidade. Vicente/Vera ameaça Robert com uma faca e diz, "corto meu pescoço e acabo com seu brinquedo". A questão aqui não é só morrer, mas é acabar com o plano (a vingança) do outro, matar seu projeto de dominação. Vicente corta o próprio pescoço. A cena é forte, o sangue esguicha por cima do body, e ele/ela cai. Segunda tentativa de suicídio: modo de acabar com o 
sofrimento, não há outra saída.

Vicente/Vera tenta o suicídio duas vezes. Atentemo-nos para o significado deste gesto, pois este evidencia que ele/ela não queria se matar de fato. Por toda a trama Vicente mostra esperança; quer recuperar seu passado, sua história, espera por seu futuro; deseja um; pode colocar-se no modo do devir, apesar de toda a transformação radical sofrida em seu corpo-próprio (Leib), o qual atravessa seu projeto existencial. Ao dizer a Robert, corto meu pescoço e acabo com seu brinquedo, Vicente escolheu matar a opressão, interromper o ciclo de violência contra seu corpo-próprio e si próprio. Neste momento, não escolheu matar-se. Esta segunda tentativa de suicídio mostrou-se mais desesperada, pois Vicente corta o próprio pescoço com uma grande faca, adentrando no limite da existência, para muito além dos simples cortes no pulso; mesmo assim, a intenção mostrada é a de não se matar, mesmo sendo a morte a consequência dela.

$\mathrm{Na}$ cena 13 (00h38min) acontece o acidente de carro, e Gal é encontrada carbonizada; vida por um fio. Apesar de a traição ter sido a causa do acidente, Robert a salva, no último momento. O limite entre a vida e a morte está presente em vários momentos do filme, em um vaivém, um intercâmbio de possibilidades de ser e não ser de modo tão intenso e rápido, que nos coloca diante da nossa condição primordial de contingência mundana.

Robert cuidou de Gal incansavelmente e, quando aparece um sopro de vida e ela consegue manter-se em pé, o trágico volta a acontecer: o suicídio. Gal jogou-se no vazio. Sua filha Normita, ainda criança, assiste ao suicídio; a mãe cai sobre seus brinquedos no jardim.

Sobre a morte, Pompéia (2014), embasando seu pensamento nos ensinamentos de Heidegger, diz que "melhor que o substantivo, o verbo morrer nos fala daquilo tudo que diz respeito à morte do homem: poder morrer, ter de morrer, querer morrer, quando morrer, por que morrer, não querer morrer” (p. 69). Será que o suicídio é sempre um querer morrer?

Na cena 27 (01h14min) aparece o segundo suicídio do filme, a filha Norma também se atira da janela.

Ao analisarmos o projeto existencial dos personagens, não incluímos Norma nas análises porque sua personagem vaga no transcurso da história de modo a não se apropriar do sentido da sua vida. O suicídio, isto é, a morte, passa então a ser uma possibilidade para acabar com o vazio em que o sujeito se encontra, com "a ausência radical de qualquer significação" (POMPÉIA, 2014, p. 74). Diferentemente de sua mãe, que busca o suicídio 
como recusa; não há possibilidade de viver com o corpo queimado, com aparência de monstro.

Marilia diz, na cena 13 (00h38min): "Não parecia um ser humano. Era uma faísca."

Gal revela que não poderia continuar viva naquela condição; o desespero foi maior do que a capacidade de viver. Na questão do suicídio, assim como nas tentativas de suicídio de Vicente, o fato objetivo pode ser o mesmo (suicídio); no entanto, como gestos, são diferentes.

O filme mostra uma tentativa de assassinato.

Cena 45 (01h42min): com uma arma, Robert ameaça seu colega, que descobriu sobre Vicente.

Ocorrem também três assassinatos: o de Zeca, o de Robert e o de Marilia. Estes homicídios colocam a morte como a grande possibilidade de acabar com os conflitos vivenciados, quando não restam alternativas. Os personagens vivem situações-limite, e a forma de solução encontrada está sempre na agressividade, na possibilidade de matar, apontando para o caráter primitivo de cada um.

Na cena 11 (00h36min), Robert assassina Zeca; na cena 47 (01h46min), Vicente/Vera assassina Robert e Marilia. Estes assassinatos acontecem ligados à sexualidade, em cenas em que estava em curso uma relação sexual, consentida ou não, como em um estupro. Assim, ligamos a morte à sexualidade do mesmo modo como a sexualidade se liga à vida em sua origem do nascimento. A vida então aparece no filme, ligada à sexualidade e ao gênero, pois, ao lado de várias mortes, como as de Gal, Norma, Zeca e Robert, acontece um novo nascimento, o da mulher Vera. Vicente morreu para que Vera aparecesse? Sem considerações éticas ou morais, podemos dizer que a vida não é direito ou dever; ela é uma contingência mundana. É-nos dada de graça, a partir do lançamento. Cabe ao homem atribuir sentido a ela, assim como atribuir sentido à morte. "É a liberdade do que não é necessário. É a forma de liberdade que diz respeito a entes que, não precisando existir, contudo existem e, uma vez existindo, têm a responsabilidade pela existência, que é a oportunidade de realizar, de gestar significações, obras, tarefas, conhecimentos" (POMPÉIA, 2014, p.80). "É a perspectiva do sentido que permite transformar a morte num gesto próprio” (POMPÉIA, 2014, p. 79).

Assim como Robert tentou salvar Gal, tenta também salvar Vera.

Na cena 33 (01h23min), após Vicente cortar o próprio pescoço, Robert desce as escadas correndo, larga a arma no chão, pega Vicente no colo e sai. 
Robert quer salvar a pessoa ou o experimento? Em seu modo de ser-com objetificante, pode-se levantar a questão nos dois episódios envolvendo as tentativas de salvar o outro. Robert é comandado pela obsessão de um corpo perfeito, salva Gal em consequência; porém, talvez sua intenção primeira seja a criação da pele artificial. Da mesma forma, Robert quis salvar Vera, sua criatura, seu objeto de uso e prazer, não Vicente, pois a pessoa deste pouco lhe importava. No entanto, no final, salva a pessoa que se mostra como Vicente e como Vera.

Também é possível pensar a partir desta perspectiva quando, na cena 23 (01h06min), a mãe de Vicente fica sabendo do desaparecimento do filho e do acidente com moto, e pergunta sobre o corpo. Se não há um corpo, não há uma morte, uma vez que uma morte sem corpo parece não morte.

Outro aspecto que pode ser abordado é a questão da morte simbólica, tal qual ocorrida com Vicente, ao longo da trama, quando este é transformado em mulher, à revelia; seu projeto de ser homem foi morrendo. A perda do projeto e a perda do sentido levam o sujeito a uma morte existencial, a qual logo pode se converter em morte concreta. Vicente perdeu o sentido de sua vida; seu sonho morreu de modo drástico e intenso; sonho como expectativa de um futuro específico, dado por sua história pregressa e suas vivências no mundo-vida; sonho como perspectiva do desejo, inclusive o sexual. Privado do sentido, tudo o que Vicente esperava, tudo a que se dedicava em nome de que organizava sua vida, morreu. Embora o sonho tenha acabado, a possibilidade de sonhar permaneceu; assim, é na arte (inicialmente na escultura, modelando corpos exteriores e, ao mesmo tempo, modelando seu novo corpo, o Leib), que Vicente encontra a possibilidade de restabelecer um sentido.

\subsection{Modos de transformação do corpo. Presença do gênero/feminino/masculino}

Esta IN se volta para o corpo de Vicente em transformação em corpo de Vera. É um processo demorado, que exige muito trabalho, conhecimento, técnica e cuidado por parte do médico, Robert; este processo também exige das ações realizadas por Vicente/Vera, aceitando ou rejeitando essa mudança. A IN também se concentra na intenção de Zeca de transformar seu rosto, para não ser reconhecido, e nos cuidados médicos com Gal, cujo corpo é transformado pelo fogo.

A transformação do corpo de Vicente dá-se inicialmente pela vaginoplastia. Prisioneiro de Robert, nada sabia a respeito do motivo que o levou àquela situação. $\mathrm{O}$ 
único preparo pré-operatório a que fora submetido enquanto estava consciente foi a raspagem da barba, feita por Robert. Após, Vicente foi dopado e, ao acordar, viu-se na mesa cirúrgica, já operado. Ao perguntar o que ocorrera com ele, Robert responde, com frieza: "você foi submetido a uma vaginoplastia". Vicente fica atordoado com a notícia, o que revela seu não consentimento e, mais ainda, mostra que sua intencionalidade não estava direcionada a uma mudança do gênero masculino para o feminino. É submetido à ordem de Robert, que afirma ter sido bem-sucedida a cirurgia mas, devido ao fato de os tecidos permanecerem macios, Vicente deve se exercitar com aparelhos dilatadores para manter aquele orifício aberto. Há que ter muito cuidado, pois aquele é o orifício por onde seu corpo respira. Para tanto, ele deve se valer de dilatadores de tamanhos diferentes, começando pelo menor. É um orifício que comanda sua existência, já que produz libido, energia vital do querer, da vontade, da excitação sexual. A cena em que Robert dispõe os dilatadores em sequência de tamanho e se dirige a Vera é mantida pelo clima de terror e de excitação. Ela expressa vivências de Vicente se transformando em Vera, que vai descobrindo o poder da vagina.

Cena 31 (01h20min): Vicente sobe na cadeira para olhar seu corpo no espelho e abre o roupão; o novo corpo, a amputação; a operação foi um sucesso, mas os tecidos que formam a vagina estão ainda macios e poderiam aderir uns aos outros; transformação da vagina (o corpo e o tempo); Vicente tem que manter aberto o novo orifício; apesar de ele não ter escolhido a vaginoplastia, não há caminho senão o de aceitar e cuidar daquele novo corpo, colaborar com seu destino.

Cena 31 (01h21min): Vicente aparece em posição ginecológica e Robert o examina; a chegada do feminino.

A mudança de gênero masculino para o feminino se dá aos poucos, mediante outras intervenções, como a prótese de seios, por exemplo. Porém, são duas que se destacam: a pele perfeita criada em laboratório por Robert e colocada no corpo no rosto de Vicente.

A pele, sentida pelo tato de Robert ao deslizar sua mão sobre os seios de Vicente/Vera, no momento em que está suturando cortes feitos por Vicente na tentativa de mutilação ou mesmo de suicídio, coloca Robert diretamente em contato com sua criação, isto é, a mulher que está surgindo. Sente prazer ao perceber a maciez da pele, ao ver sua beleza. Vera o olha, percebendo o que Robert sente, e desvia o olhar. Vemos um 
indício de perceber-se desejada por um homem. Robert sente, com o tato, a superfície da pele de Vera, sente sua maciez e suas saliências e, se concordarmos com Husserl quando este diz "[...] mas se considero a mão e o dedo dou-me conta que eles têm sensações de contato que continuam ainda quando a mão se recolhe; assim, o dedo e a mão têm sensações cinestésicas [...]" (HUSSERL, 2002, p. 149), podemos dizer que ele se dá conta daquelas sensações de contato que continuam a serem por ele sentidas.

Quando Robert está proferindo uma palestra para a comunidade científica sobre seus experimentos com o desenvolvimento de uma pele artificial, a qual é humana em aparência e melhor do que esta em resistência, afirma que o rosto nos identifica. Como médico sabe que, para salvar alguém de um incêndio, é preciso, além de salvar-lhe a vida, dar a esta pessoa um rosto dotado de feições que permitam-na gesticular, expressar emoções.

Ao desvendar o rosto de sua criação, quando tira a máscara cirúrgica de Vicente, Robert fica extasiado. Entendemos que este sentimento se deve à recriação de Gal e a sua própria genialidade. Dá um nome à sua criação, Vera. Esta passa a ter uma identidade, em decorrência do seu rosto. É certo que todo o corpo e sua forma compõem essa identidade, mas esta é trazida à fala pelo rosto. É um momento em que Vicente se percebe chamado por um nome feminino, percebendo também que a aparência do feminino apraz à Robert.

Cena 33 (01h23min): o rosto de Vicente se transforma e aparece com uma máscara: a transformação do corpo, corpo plástico, corpo objeto; surge um corpo perfeito de mulher; há desenhos de recortes por todo o corpo nu; parece que Vicente foi recoberto com pele artificial retalho a retalho, montado.

O esforço de Robert para cuidar desta pele é tão intenso, que impõe a Vera o uso de uma segunda pele artificial, os collants preto e bege que devem ser vestidos tanto para firmar o contorno do corpo, como para proteger a pele. Nota-se que a transformação está quase completa, pois nesta cena a voz de Vera já é feminina.

O conhecimento da ioga por intermédio de um programa de televisão coloca Vera em contato com a filosofia desta prática; também desperta nela o interesse de aprender aqueles exercícios. Estes vão contribuindo para a maior plasticidade do seu corpo-próprio e para sua forma, a qual vai se tornando sensual e delineada. Ela se vê nos espelhos e percebe-se sendo vista, com interesse, por Robert, no circuito interno de TV da mansão. Vera não deixa de realizar os alongamentos e outros exercícios devido ao fato de estar 
sob o olhar de Robert; ao contrário, continua e o olha, colocando-se em evidência.

Também vão sendo postos à disposição de Vicente/Vera produtos que contribuem com a aparência feminina, como lápis, pincéis e produtos de maquiagem, além de vestidos. De início Vicente rejeita tudo isso, ficando apenas com o lápis. Porém, aos poucos vai se valendo do restante oferecido a ele.

Quando Robert vai ao quarto de Vera para com ela fumar ópio, uma prática comum entre eles, as perguntas por ela colocadas o irritam e, então, intenciona se retirar; entretanto, ela se insinua e busca beijá-lo, dizendo sou sua, feita em sua medida e você acabou de me dizer que gostou. Ela afirma que sabe que ele a olha, indicando com movimento de cabeça que é pelos monitores do sistema de segurança da casa.

A percepção de si, como mulher desejada, dá-se de modo mais materializado e brutal quando Zeca a vê em um monitor e ela se dá conta de estar sendo admirada e desejada. O clima que Zeca estabelece é de brutalidade, de desejo animalesco; ele então a estupra. Trata-se de uma violência que deixa suas marcas. Ela se sabe mulher e Robert passa, com maior ênfase, a olhá-la como tal, e dela cuidar. Há, certamente, uma zona obscura de motivos que levam Robert a ter este cuidado: a preservação tanto da obra como a do objeto de seu desejo. Ela aceita o jogo: assume o papel de mulher. Veste-se com sensualidade e se maquia. Dorme com Robert, que se mostra apaixonado por ela, e ela por ele. É um jogo? Vivências que vão se dando na temporalidade vivenciada ao estar junto com ele e vão se entrelaçando, constituindo percepções de si e do mundo como pertencente ao gênero feminino? Sim, são vivências em corpo-próprio que sente desejo e que se sente desejado; que sente prazer ao ser tocado pelo outro com quem está.

Ela se assume mulher, inclusive preparando o café da manhã para o marido que ainda dorme. Acorda-o com um beijo, vestida com uma camisa que deixa, sensualmente, seus seios visíveis. Este modo de conviver vai se impondo e chega o dia em que ela recebe permissão de Robert para sair com Marilia às compras.

Cena 43 (01h39min): Vera aparece com um vestido decotado, linda e diz: coloquei o salto para ir treinando; parece encarnada no corpo feminino, aceitando sua nova condição; parece querer treinar esse modo de ser para o futuro.

Ao permitir que Vera saia com Marilia para fazer compras, Robert se mostra homem provedor disposto a atender às vontades da mulher: coloca à disposição dela cartões de crédito para comprar o que quiser. Ao chegar, ela desce do carro, carregando bolsas e sacolas. Adentra o escritório em que Robert se encontra sendo questionado por 
Fulgencio a respeito da vaginoplastia que realizaram em um rapaz muito jovem, há seis anos. Fulgencio mostra uma matéria publicada no jornal daquele dia relatando o desaparecimento do jovem; a reportagem mostra fotos de Vicente. Vera se dirige a Robert, sentando-se em seu colo e beijando-o; confirma que ela quis a transformação e que está feliz. Após Fulgencio se retirar, ela o beija apaixonadamente. Nesta cena (e em outras) testemunhamos a presença de uma jovem mulher, bonita e apaixonada. A transformação do gênero masculino em gênero feminino está configurada. Entretanto, no fluxo da consciência, as vivências de Vicente são passíveis de serem trazidas pela lembrança. Constituem, também, aquele corpo-próprio que é o de Vicente/Vera.

Antes de ser raptado por Robert, quando Vicente está no atelier de sua mãe, vemos uma cena significativa, em que Vicente esta vestindo, com cuidado, um manequim de aparência feminina. Ao terminar, conversa com Cristina, tentando seduzi-la. Evidenciase um clima de sedução. Ele quer presentear Cristina com um vestido de seu gosto, convidando-a a sair com ele naquela noite. Cristina não aceita, pois diz que vai sair com sua namorada. O gênero dual feminino/masculino está se mostrando em Vicente? O gênero feminino estaria se destacando em relação ao masculino?

Em determinada cena, já como Vera, Vicente tem uma relação sexual intensa, mas consentida, com Robert, a qual é sustentada por um clima de tensão e de desejo entre os dois. Dada a dor ainda sentida por Vera, Robert propõe sexo anal. O corpo-próprio de Vicente/Vera se doa às vivências homossexuais e bissexuais?

Olhando da perspectiva da Antropologia Dual trazida neste artigo, em vez de fixa e imutável, a polaridade gênero masculino e gênero feminino (cujas características são biológicas) é genético-dinâmica e qualitativa-experiencial. As vivências de cada pessoa, que se dão em contextos socioculturais junto ao outro influenciam, e muitas vezes se impõem, às escolhas de vida. Os atos vivenciais de uma pessoa não são previsíveis, porque a subjetividade é algo único, que não se repete. Há um núcleo de personalidade, conforme Ales Bello (2017, p. 65) diz ao citar Stein, núcleo este que se manifesta no desenvolvimento da pessoa empírica, tornando-a uma pessoa unitária, com qualidades individuais, a exemplo de um eixo em torno do qual a pessoa realiza, em sua subjetividade, seus movimentos de ser.

Vemos no filme aqui discutido Vicente/Vera em processo transgênico, vivenciando experiências do gênero feminino e trazendo consigo vivências do gênero masculino, como aquelas vistas na cena em que está com Norma, intencionando manter uma relação sexual com ela. 
Na última cena do filme, Vera entra no atelier de sua mãe e diz sou eu, Vicente. O corpo-próprio de Vera/Vicente é o de uma pessoa (ser humano) unitária, com qualidades individuais. A realização desta pessoa com suas vivências de ambos os gêneros está no aí do mundo-vida, aberta às possibilidades que se apresentarem e às escolhas que fizer.

\subsection{Temporalidade-espacialidade}

O centro em que a trama se desenvolve é a mansão do Dr. Robert Ledgard, em Toledo, Espanha. Como toda mansão, tem muitos aposentos, os quais abrigam também os laboratórios de investigações científicas realizadas por ele. A casa inclui um centro cirúrgico onde são realizadas cirurgias plásticas, inclusive as transgenitais. As cirurgias são realizadas por uma equipe médica.

É nessa cidade e nessa mansão que Vicente se torna o alvo da vingança de Robert, que o aprisiona em 2006 e o mantém prisioneiro até 18/01/2012, quando há o desfecho violento em que Vera mata Robert e Marilia, libertando-se do cativeiro.

A temporalidade vivenciada por Vicente/Vera não pode ser descrita apenas em termos cronológicos, embora seja importante apontar os anos de aprisionamento que revelam a longevidade do processo de transformação. Conforme entendemos, é importante trazermos os modos pelos quais Vicente/Vera vivenciou a temporalidade que se estende na espacialidade.

Seguindo Minkowisk (1995), entendemos o fenômeno do tempo como um caleidoscópio que, sem cessar, faz espelhar, a cada instante, imagens diferentes, ideias em formação, percepção de mundo, do outro e de si mesmo; tempo visto como fenômeno que revela a vida nas vezes de um turbilhão de acontecimentos diferenciados e caóticos que não oferecem um porto seguro.

Entendemos que vamos escorregando na temporalidade vivenciada, de um presente, do agora, para um passado, o já foi, trazendo um futuro, como expectativas e intencionalidades que se dirigem para o que há a fazer. Tal visão é consonante com aquela dada por Husserl (1994), para quem há um fluxo da consciência que se faz pela preservação do presente, indicando algo que o sucederá. Há um fluir nas vivências que revela a duração dos atos, mostrando o escoar do tempo, o que nos faz compreender que não se trata do tempo que acolhe o fluxo, mas do tempo que se dá no fluxo. As vivências duram e vão escorregando a partir do momento do agora, em que a ação está sendo realizada, para o já foi, antecipando ações delineadas na antevisão do porvir intencionado. 
O fluxo da consciência se revela, então, em sua continuidade, onde o presente pressupõe o passado e traz para si o futuro. Ao deslizar do agora para o já foi, a realização do ato de recordar, a lembrança, possibilita re-viver o realizado no momento presente (no agora), que já passou. Bicudo apud Barbariz (2017, p.145) nos diz que estes atos possibilitam a “[...] repetição de uma produção real, gestando a autoevidência da identidade". A ilimitada capacidade de repetição da autoevidência constitui uma cadeia de repetições; com isso, constitui-se uma identidade da estrutura dos feitos. De acordo com Ales Bello apud Barbariz (2017, p.145) "[...] na recordação, o percebido, embora não seja perceptível em carne e osso, está presente ao seu modo".

Vicente é lançado na mansão de Robert como prisioneiro. Não tem ciência do que está ocorrendo; tampouco está intencionando um projeto de mudança de gênero. É lançado, e tem que se haver com sua existência. Em condições desfavoráveis, sem qualidade de vida, permanece acorrentado, sem água ou comida. Robert traz-lhe água em uma bacia; preservando sua vida, Vicente bebe como um animal, colocando a boca diretamente na água. Quando lhe é trazida a comida, dada a fome que sente, come vorazmente. Percebe-se que este modo de comer, não condiz com os costumes de pessoa educada, e pede desculpas.

Após a vaginoplastia, Vicente é lançado em uma situação desconhecida, não planejada. Mas esse é o seu corpo-próprio. Sente o que ali ocorre. Percebe-se vivo, porém não aceita o sucedido, revolta-se contra Robert, quer sair dessa situação, fugindo do local, de sua vida. Tenta a fuga, sem sucesso; tenta o suicídio, sem sucesso. Vivências que se dão no agora e que escorregam para o já foi, podendo ser trazidas à lembrança vividamente. Estranha-se nesse corpo-próprio, porém diferente. Percebe-se refém de Robert. Apático, deixa-se manipular, aguardando o que ocorrerá.

É um tempo vivenciado na apatia, na desesperança de poder se impor e na esperança de voltar a sua casa, lugar em que habita, onde se encontram as pessoas do seu núcleo afetivo.

Robert o examina, ginecologicamente, e constata que tudo vai indo bem. Quando este comenta que tudo está em ordem, Vicente indaga: então já posso ir embora? Robert pergunta, para onde? Para minha casa. Esse é seu projeto: ir embora. Vive esse projeto à medida que a transformação vai ocorrendo, de modos diferentes. Vive-o também em sua busca por seduzir Robert, ao se perceber como mulher desejada, ao concordar com relações de intimidade com este; faz o mesmo até quando se submete a Zeca, que a violenta. O que quer é trazê-lo para seu projeto e conseguir escapar daquela prisão. 
A temporalidade vivenciada por Vera em seus longos dias, prisioneira em um quarto, ainda que com conforto, é suportada registrando ações que a fazem se dar conta de que está viva, como respiro, sei que vivo, anotando datas com referência a informações fornecidas por Marilia mediante perguntas. A última data que anota é 18/02/2012.

O filme não se passa em uma sequência linear de ocorrências, nem traz uma narrativa linear, mas é entrecortado com cenas superpostas ou que se passam em datas diferentes. O relato dos acontecimentos importantes para a manutenção da trama é realizado por Marilia, como uma porta-voz de chronos.

Cena 39 (01h33min): algumas falas de personagens definem a localização temporal do filme; Marilia é quem narra o passado, quem localiza no tempo, quem faz as articulações de sentido da história; a data escrita na parede localiza o enredo no tempo.

Por ser sabedora de ocorrências passadas e presentes e, ainda, por guardar segredos não trazidos ao conhecimento de Robert e de Zeca, Marilia é a voz que expõe o fio condutor do drama, voz esta que, como um oráculo, prevê o futuro. Conta para Vera que ambos, Zeca e Robert são irmãos; são filhos dela, porém de pais diferentes, e diz que Robert é filho do Sr. Ledgard que, com a esposa, o adota. Porém, é ela que cuida de ambos, pois permanece na casa como empregada. Diz, ainda, que os dois nunca se deram bem, que Robert e Zeca apresentam tipos diferentes de loucura. Relata as traições de Zeca e Gal quando, ao fugirem, apaixonados, sofrem um acidente, do qual Zeca foge enquanto Gal é salva por Robert, com queimaduras sérias. Relata as perdas de Robert nos suicídios da esposa e da filha. Conheceu ambas. Por este motivo, reconhece em Vera o rosto de Gal. Entretanto, ignora a mudança de gênero pela qual Vicente passou sem que fosse decisão deste.

Como um oráculo, ao ver Vera e nesta reconhecer o rosto de Gal, diz a Robert que o que ele sente por Vera irá devorá-lo como um câncer e que, quando ele se der conta, já não haverá volta.

Quando Zeca chega e toca a campainha da casa, Marilia o reconhece, fica apreensiva, pois sabe da proibição de Robert à presença dele naquela casa, ciente também do motivo. Sua preocupação aumenta quando Zeca vê Vera, a qual ele julga tratar-se de Gal. Marilia se aflige, pois parece-lhe que o passado de traição e tragédias retorna ao presente. Sua lucidez faz com que visualize o desfecho da cena. Robert, que estava ausente, chega em casa e, pelo monitor, vê a cena do estupro. Pega um revolver e sobe. Marilia, em tom de prece, modo de vivenciar a temporalidade, conforme Minkowski 
(1995), diz a si mesma: mate ambos e de depois me mate. Mas Robert mata Zeca. Marilia continua com o presságio: ou Robert mata Vera, ou ela o mata. Sua profecia se cumpre: Vera mata Robert e ela própria, Marilia.

Já a mãe de Vicente vivencia a temporalidade da ausência do filho e do desconhecimento de seu paradeiro em uma atitude de esperança (MINKOWSKI, 1995) de que ele esteja vivo. Esta esperança a mantém em estado de alerta, buscando-o, mesmo depois de seis anos de seu desaparecimento. Tanto que consegue ainda fazer com que a imprensa noticie o fato, incluindo fotos dele em reportagens.

Cena 46 (01h44min): ao ver sua foto no jornal, Vicente/Vera explicita que não abandonou seu passado, planeja algo.

Cena 49 (01h49min): Vicente, ao reencontrar sua família, seu lugar, conta sua história e localização no tempo, seis anos se passaram.

\section{Dando conta do compreendido sobre a pergunta posta}

Compreendemos que, ao mencionar a pele que eu habito, o filme que analisamos está dizendo do corpo-próprio que vivencia sensações, que percebe e se percebe em ação, sempre já estando no mundo-vida com seus cossujeitos e demais seres, isto é, ou outros com quem está. As vivências dão-se na temporalidade do ato, ocorrendo no agora, no momento em que o ato é realizado. Porém este ato tem uma duração, mesmo enquanto já vai escorregando para o passado e trazendo o futuro para outro agora. Estas vivências podem ser revividas ao serem trazidas pela lembrança. Vivências e vivências de lembranças dão-se no fluxo da consciência. São entrelaçadas umas às outras, constituindo um estilo de ser da pessoa, seja esta do sexo masculino, seja do feminino. Este estilo faz dela uma pessoa dotada de um eixo que, embora dinâmico e flexível, faz com que ela se mantenha com suas qualidades individuais. Sua subjetividade é única.

Assumimos, com Ales Bello, a Antropologia Dual, a qual afirma que o masculino e o feminino se assumem de modo diverso em um fundo em que há uma igualdade já posta, concernente à pessoa, aceita em sua dignidade e autonomia. Assim, há, ao mesmo tempo, igualdade e diferença. A diferença não se coloca como polos estanques como sexo masculino e sexo feminino; mas, cada pessoa, olhada em sua individualidade, assume nuanças e especificidade em seu modo de ser. Tais especificidades vão sendo constituídas pelas suas vivências, ocorrem em contextos socioculturais e, junto ao outro, influenciam 
e, muitas vezes, impõem escolhas. Em suas vivências, o corpo-próprio experiencia o mundo externo com seus órgãos sensoriais, pela percepção e pela empatia. Ao ser-com o outro no mundo, a percepção de si como igual e como diferente do outro vai se realizando. E esta realização vai tomando os caminhos indicados por suas tendências pessoais, por suas escolhas, pelos modos de estar-com o outro, por situações vivenciadas, não raro, sem terem sido escolhidas que, contudo, se apresentam à vida de modo contingencial. É neste movimento de tornar-se ou de vir-a-ser, que se dá no fluxo da vida, que a sexualidade de cada um vai se delineando e afirmando como um modo de ser.

Entendemos, portanto, que o corpo-próprio, ao vivenciar experiências junto ao outro em contextos socioculturais específicos, vai se constituindo em sua totalidade física-psíquica-espiritual de modo a manter a igualdade e a diferença. Diferença posta tanto nos aspectos biológicos de apresentar-se no gênero masculino ou no feminino, incluindo também nuanças de modos de ser de um ou de outro gênero, podendo, inclusive, apresentar-se com tendências que dizem de ambos os sexos.

\section{Referências}

A PELE QUE HABITO (La piel que habito). Ano: 2011. País: Espanha. Diretor: Pedro Almodóvar. Roteiro: Pedro Almodóvar e Agustín Almodóvar. Atores principais: Antonio Banderas, Elena Anaya e Jan Cornet. Duração: 115 minutos

ALES BELLO, A. Tutta colpa di Eva. Antroplogia e religione dal femminismo alla gender theory. Roma: Lit. Edizioni Srl, 2017.

ALES BELlO, A. Pessoa e Comunidade. Comentário: Psicologia e Ciência do Espírito de Edith Stein. Tradução de M. Mahfoud e Ir. J. T. Garcia. Belo Horizonte: Ed. Artesã, 2015.

BARBARIZ, T. A. M. A construção do conhecimento Matemático em um curso de Matemática à Distância. 2017. 451f. Tese (Doutorado em Educação Matemática) - Instituto de Geociências e Ciências Exatas, Universidade Estadual Paulista "Júlio de Mesquita Filho", Rio Claro, 2017. Disponível em: <http://bit.ly/2FeSSMR>. Acesso: 1 mar. 2018.

BICUDO, M.A.V. Pesquisa qualitativa segundo a visão fenomenológica. 1. ed. São Paulo: Editora Cortez, 2011.

BICUDO, M. A. V. A constituição do objeto pelo sujeito. In: TOURINHO, C.D.C. (Org.). Temas em Fenomenologia. A tradição fenomenológico-existencial na filosofia contemporânea. 1. ed. Rio de Janeiro: Booklink, 2012. p. 77-95.

BREDER, D.; COELHO, P. Desvelando imagens: o visível e o invisível na pele que habitamos. Revista Estudo Feministas, Florianópolis, v. 25, n. 3, p. 1489-1502, set./dez. 2017. FREIRE, A. B. O que faz um corpo? Comentário em torno d'“A pele que habito". Latusa, Rio de Janeiro, n. 47, p. 1-6, dez. 2011. 
HEIDEGGER, M. Ser e Tempo. Tradução de Márcia de Sá Cavalcanti. Petrópolis: Vozes, 1988.

HUSSERL, E. The Crisis of European Sciences and Transcendental Phenomenology. Tradução para o inglês de David Carr. Evanston: Nothwestern University Press, 1970.

HUSSERL, E. Lições para uma Fenomenologia da Consciência Interna do Tempo. Lisboa: Imprensa Nacional da Casa da Moeda, 1994.

HUSSERL, E. Idee per una fenomenologia pura e per uma filosofia fenomenológica. Torino: Einaudi, 2002.

MARIA POESIA. Resenha do filme "A pele que habito" (04.01.2012). Disponível em: <http://www.recantodasletras.com.br/resenhasdefilmes/3421619>. Acesso em: 05 fev. 2018.

MERLEAU-PONTY, M. Fenomenologia da Percepção. Tradução de Carlos Alberto de Moura. São Paulo: Martins Fontes, 1994.

MERLEAU-PONTY, M. Fenomenologia da Percepção. Tradução de Carlos Alberto de Moura. São Paulo: Martins Fontes, 1999.

MINKOWISK, E. Le Temps Vécu. Paris: Presse Universitaire de France, 1995.

PESSANHA, J. G. Instabilidade Perpétua. São Paulo: Ateliê Editorial, 2009.

POMPÉIA, J. A.; SAPIENZA, B.T. Na presença do sentido: uma aproximação fenomenológica a questões existenciais básicas. 2. ed. São Paulo: EDUC; ABD, 2014.

SILVA, A. A. A produção do conhecimento em educação matemática em grupos de pesquisa. 2017. 586f. Tese (Doutorado em Educação Matemática) - Instituto de Geociências e Ciências Exatas, Universidade Estadual Paulista "Júlio de Mesquita Filho", Rio Claro, 2017. Disponível em: <http://bit.ly/2ozgvWW>. Acesso em: 01 mar. 2018.

VIANNA, A. M. V. "A pele que habito" e a dupla subversão de gênero. Blog da Revista Espaço Acadêmico, Ano XVII, mensal, 23/03/2013. Disponível em: https://espacoacademico.wordpress.com/2013/03/27/a-pele-que-habito-e-a-dupla-subversao-degenero/. Acesso em: 02 fev.2018.

Recebido em: 05 de março de 2018.

Aceito em: 17 de julho 2018. 